\title{
Carrageenans as heat stabilisers of white wine
}

\author{
S. Ratnayake ${ }^{1}$, V. Stockdale ${ }^{2}$, S. Grafton ${ }^{2}$, P. Munro², A. L. Robinson ${ }^{2}$, W. \\ Pearson $^{3}$, J. M. McRae ${ }^{3}$ and A. Bacic ${ }^{1,4}$
}

\begin{abstract}
${ }^{1}$ ARC Centre of Excellence in Plant Cell Walls, School of Biosciences, University of Melbourne, Parkville, Vic. 3010, Australia; ${ }^{2}$ Treasury Wine Estates, Nuriootpa, SA 5355, Australia; ${ }^{3}$ TheAustralian Wine Research Institute, Glen Osmond, SA 5064, Australia; ${ }^{4}$ La Trobe Institute for Agriculture and Food, La Trobe University, Bundoora, Vic. 3086,
\end{abstract} Australia

Corresponding author: Dr Vanessa Stockdale, email vanessa.stockdale@tweglobal.com Short title: Carrageenans as heat stabilisers of white wine

This is the author manuscript accepted for publication and has undergone full peer review but has not been through the copyediting, typesetting, pagination and proofreading process, which may lead to differences between this version and the Version of Record. Please cite this article as doi: 10.1111/ajgw.12411

This article is protected by copyright. All rights reserved. 


\begin{abstract}
Background and Aims: Carrageenan addition has been previously shown to remove proteins from wine and to heat-stabilise wines, however, many types of carrageenans are now available with potentially different protein-adsorbing properties. This study investigated a range of commerciallyavailable carrageenans added at several stages of winemaking for efficacy of protein removal, heat stability and impact on wine sensory properties.

Methods and Results: In preliminary screening trials, 11 types of carrageenan were added to Chardonnay wine and the heat stability of the wine measured with a heat test. Three of the carrageenans successfully heat-stabilised the wines and were included in large-scale winemaking trials: sodium-rich kappa $(k \mathrm{~N})$, potassium-rich kappa $(\mathrm{kK})$, and kappa/iota $(90: 10, k i)$ carrageenan. Each carrageenan was added at three stages of winemaking, to juice, during fermentation and to wine. All carrageenans produced heat-stable wine regardless of time of addition. Addition of $k \mathrm{~N}$ during fermentation also improved wine recovery compared to bentonite addition, the positive Control, although sodium concentration also significantly increased in the wine. Addition of $k \mathrm{~K}$-carrageenan to either wine or clarified juice was the most effective treatment for producing heat-stable wine with minimal impact on the sensory profile, wine lees, turbidity and concentration of metal ions compared to that of untreated Control wines.
\end{abstract}

Conclusions: Kappa- and kappa-/iota-carrageenans can be effective at heat stabilising white wines without negative impact on sensory properties, although the filterability and concentration of metal ions of the wines can vary with carrageenan structure and time of addition.

Significance of the Study: Kappa-carrageenan, a renewable fining agent, is effective in heat stabilising wines and maybe become a useful alternative to bentonite. 
Keywords: bentonite, heat stability, kappa-carrageenan, kappa-/iota-carrageenan, lambdacarrageenan, white wine protein haze

This article is protected by copyright. All rights reserved. 


\section{Introduction}

Grape pathogenesis-related proteins (PRPs), including thaumatin-like proteins (TLPs) and chitinases, are the major soluble proteins found in grape juice and are responsible for the formation of hazes in white wine (Tattersall et al. 1997, Vincenzi et al. 2011). These hazeforming proteins survive the winemaking process but during transportation and storage, when wine can be exposed to unfavourable environmental conditions, they can undergo aggregation resulting in the appearance of a haze ( Waters et al. 2005, Vincenzi et al. 2011, Van Sluyter et al. 2015). These hazes are commercially unacceptable and therefore the hazeforming proteins must be removed before bottling. The current method of protein stabilisation in commercial white winemaking is by adding bentonite, a cheap, absorbent clay that is an efficient fining agent that binds grape proteins and removes them through sedimentation (Muhlack et al. 2006, 2016). The use of bentonite, however, has some negative aspects, such as loss of wine volume, incompatibility with filtration equipment, and sustainable waste disposal challenges (Majewski et al. 2011). Furthermore, the use of bentonite, particularly at high dose, can remove phenolic substances, flavour and aroma compounds and therefore cause an inadvertent loss of flavour in the wine (Lambri et al. 2013, Dordoni et al. 2015, Vincenzi et al. 2015). An alternative, cost-effective, fining agent would therefore be desirable to the wine industry.

Protein stabilisation using polysaccharides, such as carrageenans, is well established in the milk and brewing industries (Duan et al. 2006). Previous reports of the addition of carrageenans to white wine and grape juice for haze stabilisation have shown that they can be effective when added either during wine processing or to the finished wine (Cabello-Pasini et 
al. 2005, Marangon et al. 2012, 2013). Carrageenans are naturally occurring polysaccharides extracted from red seaweeds of the Rhophyta species (Necas and Bartosikoya 2013) and are therefore a potential renewable heat-stabilising agent. They are also a permitted additive to wine in Australia, New Zealand, Europe and the USA (Food Standards of Australia and New Zealand 2017). These polysaccharides are composed of a galactan backbone of alternating 1,3-linked- $\beta$-D-galactopyranosyl (Gal) and 3,6-anhydro-D-galactose (AnGal) residues with a molecular mass between $200-800 \mathrm{kDa}$ and can contain sulfate ester $\left(\mathrm{SO}_{3}{ }^{-}\right)$groups. There are three commercially-available structural types of carrageenans, namely kappa(k-, one $\mathrm{SO}_{3}$ residue per disaccharide), iota (i-, two $\mathrm{SO}_{3}$ - residues per disaccharide) and lambda ( $\lambda$-, three $\mathrm{SO}_{3}$ - residues per disaccharide). These sulfate ester polysaccharides are widely used in industrial applications in which kappa-carrageenans (G4S-DA repeat) and iota-carrageenans (G4S-DA2S repeat) are employed for their gelling properties and lambda-carrageenan (G2SD2S6S), a non-gelling carrageenan, as a thickening agent. Strong interactions between the sulfate ester groups of neighbouring helices, mediated by potassium $\left(\mathrm{K}^{+}\right)$and calcium $\left(\mathrm{Ca}^{2+}\right)$ ions, are responsible for stabilising the three-dimensional structures of kappa- and iotacarrageenans, respectively (Janaswamy and Chandrasekaran 2002). Carrageenans naturally occur as a $\mathrm{K}^{+}$salt, although they can be modified to the sodium $\left(\mathrm{Na}^{+}\right)$salt through a patented ion exchange process (Campo et al. 2009, Trudsoe 2010). Kappa-carrageenan as the $\mathrm{Na}^{+}$salt is soluble in cold water and delays the aggregation of the helix structure thereby forming a hard gel.

Carrageenan has previously been shown to heat-stabilise white wines (Marangon et al. 2012, 2013), however, the impact of different carrageenan structures and times of addition on 
winemaking processes and wine properties is unknown. In the current study, an initial screening was undertaken of several commercially-available carrageenans of varying structure types in a Chardonnay wine. From this initial screening process, the carrageenans that were identified as more effective at heat stabilising wines were selected for pilot winemaking trials. The impact of the addition to juice, wine or fermentation of different carrageenans, including kappa-carrageenans with either $\mathrm{Na}^{+}, \mathrm{K}^{+}$ions or blended with iotacarrageenan, was explored in pilot-scale winemaking for heat stabilisation, fermentation time, wine recovery, clarity and filterability, concentration of metals and sensory profiles.

\section{Materials and methods}

Heat-stabilising and clarification agents

Carrageenans with different structures were obtained from CPKelco ApS (Lille Skensved, Denmark), Cargill Australia (Melbourne, Vic., Australia) and Herbstreith \& Fox (Neuenbürg, Germany). Low-methyl citrus pectin (LM) was obtained from Herbstreith \& Fox and bentonite (SIHA Active G, 0.5\% sodium 0.8\% calcium) was from E. Begerow, Langenlonshiem, Germany. Details of the carrageenan batches are shown in Table S1. Clarification agents tested prior to carrageenan addition included pectinase enzymes (polygalacturonase, VinoClear, Novozymes, Copenhagen, Denmark), a chitosan-based clarification agent [Qi-Up, comprising tartaric acid (47\%), pea protein (33\%), and chitosan (20\%), Institut Oenologique de Champagne, Mardeuil, France], and a combined enzyme treatment [referred to as 'E2', 50:50 blend of endo- $\beta$-glucanase (Viscozyme) and cellulase (NS26215) enzymes (Novozymes, Copenhagen, Denmark)].

Stock solutions for protein removal

This article is protected by copyright. All rights reserved. 
Stock solutions of carrageenans (10 g/L) were prepared for addition to either juice, ferment or wine to remove proteins. Stock solutions were prepared in the same media as the sample to be treated (juice, ferment or wine) and the volume required was removed from the vessel, mixed with the required dose of carrageenan, and returned to the original vessel to avoid dilution effects. Stock solutions were freshly prepared by slowly adding carrageenan (2 g) to either juice, ferment or wine (200 mL) while mixing using a mixing stirrer (ES Overhead Stirrer with stirring shaft with propeller, Velp Scientifica, Usmate, Italy) for at least 2 min until all material was in solution. Bentonite stock solutions (250 g/L) were prepared with water and included in the preliminary heat stabilisation trials and large-scale winemaking trials as positive Controls.

\section{Carrageenan characterisation}

Carrageenans were characterised for water- and wine-solubility using Viscosity Index measurements. Carrageenan solutions (1.5\% w/v; $15 \mathrm{~g} / \mathrm{L})$ were prepared in both water and wine (Chardonnay) and the Viscosity Index of each solution was visually rated on a scale of 1-6, where 1 = low viscosity (liquid), 6 = high viscosity (solid). To determine total carbohydrate concentration, each carrageenan (200 mg) was dissolved in $\mathrm{H}_{2} \mathrm{O}$ to which four volumes of absolute EtOH were added. After $18 \mathrm{~h}$ at $4^{\circ} \mathrm{C}$, the solution was centrifuged, the pellet washed twice with EtOH, acetone and methanol, dried under vacuum and weighed. Carrageenan structures were elucidated using linkage composition analysis (Stevenson and Fumeaux 1991) and sulfate ester content (Craigie et al.1984), as well as ${ }^{1} \mathrm{H}$ NMR spectroscopy $\left(\mathrm{D}_{2} \mathrm{O}, 80^{\circ} \mathrm{C}\right.$, Bruker Avance III $600 \mathrm{MHz}$ spectrometer with cryo-probe, Bruker Daltonics, Bremen, Germany) as a single-step analytical method to identify different types of 
carrageenan (Figure S1 and Table S2). Carrageenans have been characterised extensively with ${ }^{1} \mathrm{H}-\mathrm{NMR}$ and the diagnostic chemical shifts for the key structural units are published (Van de Velde et al. 2002). Molecular size distribution (data not shown) was determined using size-exclusion chromatography with an Agilent 1100 HPLC (Agilent Technologies, Santa Clara, CA, USA) with a Shimadzu RID-10A refractive index detector (Shimadzu, Kyoto, Japan), GRAM $1000 \AA ̊$ column (PSS Polymer, Mainz, Germany) at $80^{\circ} \mathrm{C}$, and dimethylsulfoxide (DMSO) with $0.5 \%$ lithium bromide ( $\mathrm{LiBr}$ ) isocratic solvent system, 0.3 $\mathrm{mL} / \mathrm{min}$ flowrate. Structures were found to be similar to the product specifications, as expected, and batches of the same type of carrageenan were compositionally the same regardless of sample code or production year.

\section{Heat-stabilising trials}

The efficacy of different carrageenans in producing heat-stabilised wines was assessed in preliminary heat-stabilising trials with a Riverland Chardonnay wine [Treasury Wine Estates (TWE), Nuriootpa, SA, Australia]. Carrageenan stock solution (10 g/L in wine) or bentonite stock solution ( $250 \mathrm{~g} / \mathrm{L}$ in water) were added to wine samples (150 $\mathrm{mL}$ each in triplicate) to give a final concentration between $0.2-1.4 \mathrm{~g} / \mathrm{L}$ in $0.2 \mathrm{~g} / \mathrm{L}$ increments. Samples were then shaken to mix and kept overnight at room temperature before filtering at $0.45 \mu \mathrm{m}$ (Ultipor N66, Pall Corporation, New York, NY, USA) and assessing the heat stability of each sample as previously described (McRae et al. 2018). The concentration of each heat-stabilising agent that produced a change in turbidity before and after heat treatment $\left(80^{\circ} \mathrm{C}\right.$ for $2 \mathrm{~h}, 20^{\circ} \mathrm{C}$ for 3 h) of $<2.0$ NTU (Hach model 2100P nephlometer, Loveland, CO, USA) was considered the 
recommended dose. Carrageenans that heat-stabilised the Chardonnay wine at a concentration less than $1.4 \mathrm{~g} / \mathrm{L}$ were investigated further in large scale trials.

The concentration of heat-stabilising agent required to produce heat-stable wines for the large scale trials was also assessed using bench heat-stabilising trials. The dose for wine addition was determined as described above with addition of either carrageenan or bentonite at $0.2 \mathrm{~g} / \mathrm{L}$ across the range of $0.2-1.4 \mathrm{~g} / \mathrm{L}$. The dose that gave $<2.0 \Delta \mathrm{NTU}$ before and after heating $\left(80^{\circ} \mathrm{C}\right.$ for $2 \mathrm{~h}, 20^{\circ} \mathrm{C}$ for $3 \mathrm{~h}$ ) was selected. For juice addition, carrageenan was added in the same manner as with wine prior to heating, and the dose was determined as the carrageenan concentration that produced the lowest NTU after heating, to account for the interference of sugars and juice solids in the test. The addition rate to the fermentation was assumed to be the same as that for juice.

\section{Preliminary clarification trials}

Unclarified Sauvignon Blanc grape juice (2015 and 2016, Adelaide Hills, SA, Australia) was provided by TWE. For the clarification trials, juice was divided into batches for the three clarification treatments and two Controls (20 L each in triplicate) (Figure S2). For Treatment 1 (T1, chitosan treatment), juice was first settled $\left(0^{\circ} \mathrm{C}, 24 \mathrm{~h}\right)$, carrageenan stock solution added (10 g/L kappa-:iota- in $2 \mathrm{~L}$ grape juice to give $1 \mathrm{~g} / \mathrm{L}$ in $20 \mathrm{~L}$ ), further settled for $24 \mathrm{~h}$ and a chitosan-based clarification agent added (10 g/hL). Treated juice was then allowed to settle a further $24 \mathrm{~h}$ prior to racking. For Treatments 2 and 3 (T2 and T3), pectinase (3 
$\mathrm{mL} / \mathrm{hL}$ ) was added to juice and allowed to settle for $24 \mathrm{~h}$ prior to carrageenan addition. For T2 (E2 enzyme treatment), a 50:50 mixture of endo- $\beta$-glucanase and cellulase (E2 enzymes, $60 \mathrm{mg} / \mathrm{L}, 15^{\circ} \mathrm{C}$ ) was added $24 \mathrm{~h}$ after carrageenan addition and allowed to settle for a further 24 h prior to racking. For Treatment 3 (T3, pectinase treatment), no further additions were made. The time between addition of carrageenan and enzyme was to minimise any potential interference of each treatment on the efficacy of the other. Pectinase was added prior to carrageenan to prevent interactions between juice solids and carrageenan. Chitosan and E2 were added after carrageenan to assess the efficacy of these treatments in aiding the removal of protein-rich carrageenan prior to filtration. Controls included juice with either carrageenan treatment only (C1) or juice with no treatment (C2). All treated and Control juices were then fermented (in triplicate) with Saccharomyces cerevisiae var. bayanus (Maurivin PDM, Mauri Yeast Australia, Sydney, NSW, Australia) at $15^{\circ} \mathrm{C}$ to dryness (residual sugar $<2.0 \mathrm{~g} / \mathrm{L}$ ). Potassium metabisulfite was added (to approximately $30 \mathrm{mg} / \mathrm{L}$ free $\mathrm{SO}_{2}$ ) and wines were then settled $\left(0^{\circ} \mathrm{C}, 24 \mathrm{~h}\right)$, cold stabilised $\left(2 \mathrm{~g} / \mathrm{L}\right.$ potassium tartrate, $0^{\circ} \mathrm{C}, 21$ days $)$, filtered using crossflow filtration (0.4 $\mu \mathrm{m}$, Advanced Metallurgical Solutions, Lonsdale, SA, Australia) followed by $0.45 \mu \mathrm{m}$ cartridge filtration (Ultipor N66 Pall Corporation) and bottled in 750 $\mathrm{mL}$ green claret bottles. Samples were taken before and after crossflow filtration for the filtration analysis and after bottling for sensory and post-bottling analyses.

\section{Large-scale heat-stabilising trials winemaking protocol}

For the large-scale fining trials, Sauvignon Blanc grape juices were sourced from the Adelaide Hills region (South Australia) in 2015 (Wine 1) and 2016 (Wine 2), and stored at $0^{\circ} \mathrm{C}$ prior to use (up to 3 days). Wine 1 was produced from unclarified juice and Wine 2 was 
produced from juice treated with pectinase $(0.5 \mathrm{~g} / \mathrm{L}$, Ultrazym, Novozymes $)$ in line with the outcome of the preliminary clarification trials described above. Juice (2000 L) was mixed to the same turbidity and transferred to $50 \mathrm{~L}$ fermentation vessels (48 $\mathrm{kg}$ juice in each vessel). Juice was cold-settled $\left(0^{\circ} \mathrm{C}, 48 \mathrm{~h}\right)$, racked into clean vessels (turbidity $<200 \mathrm{NTU}$, Hach nephelometer), and fermented to dryness (S. cerevisiae, PDM, $15^{\circ} \mathrm{C}$ ) in triplicate.

Diammonium phosphate (DAP, $200 \mathrm{mg} / \mathrm{L}$ ) was added to each ferment after the initial $2^{\circ} \mathrm{Be}$ decrease.

Carrageenan stock solutions, kappa-carrageenan with $\mathrm{K}^{+}$ions $(k \mathrm{~K})$, kappacarrageenan with $\mathrm{Na}^{+}$ions $(k \mathrm{~N})$, and kappa-(90\%)/iota-(10\%) with $\mathrm{K}^{+}$and $\mathrm{Na}^{+}$ions $(k i)$, were prepared as described above and added to juice prior to cold-settling (Juice Addition), to ferment after a decrease of $2-3^{\circ} \mathrm{Be}$ (Ferment Addition) or to wine after fermentation and potassium metabisulfite addition (Wine Addition) (Figure S3). Doses for additions were determined using fining trials as described above for the preliminary heat-stabilisation trials. Bentonite (1.5 g/L final concentration) was added to wine for the positive Controls, wines without any additions were the negative Controls. After each addition, either the carrageenan or bentonite was mixed to ensure homogeneity and dry ice was added to the vessels during mixing to minimise oxygen exposure.

The lees volume was determined by measuring the mass of vessels before filling and after racking. Before $0.45 \mu \mathrm{m}$ filtration, Wine 1 was pad-filtered (Z6 nominal pad filter, IMCD Australia, Mulgrave, Vic., Australia) and then passed through two cartridge filters (1.0 $\mu \mathrm{m}$, absolute Pall Profile II, Pall, Cheltenham, Vic., Australia; and then $(0.45 \mu \mathrm{m}$, absolute Ulitipor N66 Nylon) whereas Wine 2 was filtered using a titanium cross flow $(0.4 \mu \mathrm{m}$, 
nominal, Advanced Metallurgical Solutions) then filtered using a nylon cartridge filter (0.45 $\mu$ m, absolute Ultipor N66 Nylon, Pall). Wines were bottled into clear punted claret bottles (750 mL, stock code 30143, O-I Glass, West Croydon, SA, Australia) and sealed with Sarantin screw caps (standard matte black stelvin, Orora Closures, Dudley Park, SA, Australia). Samples were collected before the $0.45 \mu \mathrm{m}$ filter for filterability analysis, before filtering and after bottling for protein analysis, and post-bottling for wine composition and sensory analyses.

Wine filterability and membrane analysis

The filterability of wines was measured using a filterability test as per Blue $\mathrm{H}_{2} \mathrm{O}$ filtration protocol (BHTechnologies 2015). Wine samples were taken prior to absolute $0.45 \mu \mathrm{m}$ filtration and post $1 \mu \mathrm{m}$ cartridge or after nominal $0.4 \mu \mathrm{m}$ crossflow-filtration. Wine (approximately $700 \mathrm{~mL}$ ) was added to a stainless-steel chamber and filtered through a disc filter [0.45 $\mu$ m polyethersulfone (PES) membrane, Millipore Express] under pressure ( 200 $\mathrm{kPa}$ ) and collected in a measuring cylinder. For the preliminary clarification trials, the time taken to filter $200 \mathrm{~mL}, 400 \mathrm{~mL}$ and $600 \mathrm{~mL}$ of wine was recorded to calculate the filterability index $\left(\mathrm{FI}_{\mathrm{v}}\right)\left(\right.$ Equation 1), where $\mathrm{FI}_{\mathrm{v}}>20$ was indicative of filtration issues. For the large-scale trials, the filterability index $\left(\mathrm{FI}_{\mathrm{T}}\right)$ was calculated based on time, whereby the collected volume was measured at $30 \mathrm{~s}$ intervals up to $180 \mathrm{~s}$ (Equation 2), where $\mathrm{FI}_{\mathrm{T}}>2.0$ is deemed a fail. Analyses were in triplicate.

$$
\begin{aligned}
& F I_{V}=T_{400}-2 T_{200} \\
& F I_{T}=\frac{V_{90}-V_{30}}{V_{180}-V_{120}}
\end{aligned}
$$


Wines showing filterability issues in the filterability test were investigated further using scanning electron microscopy (SEM) of the post-test filter membrane (Wilson and Bacic 2012). Briefly, square pieces of the filters (approximately $1 \mathrm{~cm}$ ) were fixed in $2.5 \%$ glutaraldehyde in phosphate buffered saline (PBS) for $2 \mathrm{~h}$ at room temperature. The filter pieces were rinsed in PBS (3 x 20 min), dehydrated by soaking (20 min) in solutions of increasing concentration of ethanol in water at 10, 30, 50, 70, and $90 \%(\mathrm{v} / \mathrm{v})$ ethanol before soaking in 100\% ethanol ( 3 x 1 h). The dehydrated filter samples were dried in a Balzers CPD030 critical point drier (BalTec, Pfäffikon, Switzerland) and then mounted flat onto aluminum SEM stubs using double sided carbon tape. The samples were then gold coated in a Dynavac Xenosput sputter coater (ProSciTech, Kirwan, Qld, Australia) and imaged in a Philips XL30 Field-emission scanning electron microscope (FEI Company, Hillsboro, OR, USA) at $2.0 \mathrm{kV}$. Digital images were captured at a magnification of $35000 x w i t h$ a resolution of 1424 x 1024 pixels.

Wine and juice composition

Analysis of basic wine chemistry included alcohol concentration, $\mathrm{pH}$, TA, volatile acidity (VA), glucose/fructose concentration, free and total $\mathrm{SO}_{2}$ and metals (Iland 2012). Sugar concentration in grape juice was measured by refractometry ( ${ }^{\circ}$ Brix) with an Atago WM-7 digital handheld refractometer(Atago, Tokyo, Japan) and by densitometry (Baumé) with an Anton Paar DMA 35 densitometer (Anton Paar, Graz, Austria ). Protein concentration of the juice and wine samples was determined using Bio-Rad Protein Assay Kit (Bio-Rad Laboratories, Hercules, CA, USA). Protein was quantified using Coomassie Brilliant Blue G- 
250 dye (Bio-RadLaboratories) with a calibration curve of bovine serum albumin as per manufacturer instructions.

\section{Sensory analysis}

For the preliminary clarification trials, sensory analysis was conducted using a balanced reference triangle test conducted in accordance with ISO 4120-1983(E) (Standards Association of Australia 1988) to determine any perceptible differences between wines produced using carrageenan treatment with or without pectinase addition. Samples were presented to panellists in $30 \mathrm{~mL}$ aliquots in three-digit-coded, covered ISO standard wine glasses at $22-24^{\circ} \mathrm{C}$, in isolated booths under colour masking sodium lighting, with randomised presentation order across judges. Thirty-two experienced, screened and qualified assessors evaluated the wines for aroma and palate and selected one sample in the set that was different from the other two samples. Data were collected using Fizz 2.47B software (Biosystèmes, Couternon, France) and statistical significance was determined using a binomial model (Standards Association of Australia 1988).

For the large-scale carrageenan fining trials, descriptive sensory analysis (Siebert et al. 2018) was used to evaluate any differences in sensory attributes of Sauvignon Blanc wine treated with the $k \mathrm{~N}, k i$ and $k \mathrm{~K}$ carrageenans at three stages of winemaking. Appropriate descriptive terms were developed by panel assessors during three training sessions and used for rating in a practice session and in the formal sessions, which were conducted over 3 days (Table 1). In the formal sessions, panellists assessed 24 wines (eight treatments in triplicate) 
twice using a modified Williams Latin Square incomplete random block design generated by Fizz 2.47B software. Aliquots of each wine $(30 \mathrm{~mL})$, were presented in random order in ISO standard wine glasses (coded and covered) at $22-24^{\circ} \mathrm{C}$ in isolated booths under daylight-type lighting. A rest of $90 \mathrm{~s}$ was enforced between samples and there was a minimum rest of 10 min between sets. Wines were assessed for appearance, aroma and palate. Each attribute was rated for intensity using an unstructured $15 \mathrm{~cm}$ line scale from 0 to 10 , with 'low' and 'high' ratings given at $10 \%$ and $90 \%$, respectively.

Statistical analysis

Sensory data were acquired and panel performance was assessed using Fizz Senstools (OP\&P, Utrecht, The Netherlands) and PanelCheck (Nofima, Tromsø, Norway ) as described previously (McRae et al. 2017). All judge responses were assessed for consistency using ANOVA of treatment, judge and ferment replicate results (Minitab, Sydney, NSW, Australia) and were found to be of required standard. Tukey's honestly significant difference (HSD) value was calculated $(P<0.05)$ and principal component analysis (PCA) (XLSTAT, Addinsoft, Paris, France ) was conducted using the correlation matrix of the mean values for the treatments averaged over ferment replicates, panellists and replicates.

The effects of adding different carrageenans during three winemaking stages compared to the untreated and bentonite Control wines were determined by one-way ANOVA, and the significance of the mean assessed by Tukey’s HSD test using GraphPad Prism statistics software (v6.04 GraphPad Software, La Jolla, CA, USA).

\section{Results and discussion}

Preliminary heat stability trials 
Carrageenans produced commercially have different composition, particularly relating to carbohydrate concentration and the concentration of associated metal ions, specifically $\mathrm{K}^{+}$, $\mathrm{Na}^{+}$or $\mathrm{Ca}^{2+}$ ions (Table 2). Of the selected carrageenans, kappa-carrageenans were most effective at improving heat stability by reducing haze formation after heating. Carrageenans incapable of heat stabilising wines contained either lambda- carrageenan or greater than $89 \%$ iota-carrageenan. These data indicated that only the predominantly kappa-containing carrageenans were capable of reducing heat haze through the potential to effectively either remove protein from wine or stabilise the protein in wine. A mixture of kappa- with iotacarrageenan for one batch was effective in heat stabilising the Chardonnay wine, whereas other blends and types of carrageenan were less effective in improving wine heat stability (Table 2). This demonstrated that the differences in the polysaccharide structures had a significant impact on the capacity to adsorb proteins from wine. Kappa-carrageenans have a single negatively charged sulfate ester group $\left(\mathrm{SO}_{3}{ }^{-}\right)$per disaccharide unit which forms a strong double helix structure as there is less repulsion between $\mathrm{SO}_{3}{ }^{-}$groups compared to that in iota- and lambda-carrageenans, which contain two and three $\mathrm{SO}_{3}{ }^{-}$groups per disaccharide unit, respectively. Lambda-carrageenans therefore do not form gels. Iota- carrageenans form gels in the presence of $\mathrm{Ca}^{2+}$ ( Necas and Bartosikoya 2013, Alba and Kontogiorgos 2018). Potassium ions neutralise the charge between the $\mathrm{SO}_{3}{ }^{-}$groups in kappa-carrageenans, because the $\mathrm{SO}_{3}{ }^{-}$groups are located externally to the helix structure and this promotes either bundling or aggregation of the helical structure forming a three dimensional network (Campo et al. 2009). The aggregated helical structure can be removed from wine by either settling or centrifugation. The mechanism for heat stabilisation of juice/wine is likely to involve the 
formation of an electrostatic complex between the negatively charged $\mathrm{SO}_{3}{ }^{-}$groups of neighbouring double helices in the kappa-carrageenan and positively charged wine proteins that entrap and precipitate the wine haze proteins through sedimentation ( Kara et al. 2006, Campo et al. 2009). Based on these preliminary trials, three carragenans were selected for larger-scale trials including natural kappa-carrageenan $(k \mathrm{~K})$, ion-exchanged $\mathrm{Na}^{+}$kappacarrageenan $(k \mathrm{~N})$ and a kappa-/iota-carrageenan blend $(k i)$ (Table S1).

\section{Viscosity of carrageenans}

The composition of each carrageenan determines its relative solubility in water and wine and may relate to the efficacy for removing proteins to heat stabilise wine. Carrageenans with a lower viscosity index can be readily mixed using standard winery equipment and may be more effectively dispersed. Higher viscosity carrageenans can also be processed with standard winery pumps or agitators and will facilitate protein removal by more efficient settling, but may be more difficult to initially disperse. Natural carrageenans contained more $\mathrm{K}^{+}$than $\mathrm{Na}^{+}$and were less soluble in water than wine. This is most likely to be due to the presence of other ions in wine that aid carrageenan solubility (Leske et al. 1997). The solubility of carrageenans depends on both their concentration of sulfate ester groups and the associated ionisable cations $\left(\mathrm{Na}^{+}, \mathrm{K}^{+}, \mathrm{Mg}^{2+}\right.$ and $\left.\mathrm{Ca}^{2+}\right)$, including the presence of other solutes in the media (Campo et al. 2009). The proportion of sulfate ester groups and equilibrium of cations and other solutes in solution determines the viscosity of the solution and the strength of the gel. Carrageenans that had been ion-exchanged with $\mathrm{Na}^{+}$, referred to as cold-stable carrageenans, had substantially lower $\mathrm{K}^{+}$concentration and greater $\mathrm{Na}^{+}$concentration compared to that of natural carrageenan. This led to greater solubility in water but reduced 
solubility in wine, potentially due to the influence of the cation on the three-dimensional structure of carrageenans in liquid (Campo et al. 2009). In solutions such as wine, ionisable cations and soluble solutes either disturb the formation of the gel or, if formed, is not as stable. The higher viscosity in wine of ion-exchanged compared with natural carrageenan is likely to be the result of the complex matrix of wine suggesting that the ionic composition and other soluble solutes in wine/juice are likely play a role in affecting its structure (Kara et al. 2006). A comprehensive study of both types of kappa-carrageenan salts is needed to fully understand the differences in solubility.

Effect of juice clarification agents on wine filterability after carrageenan treatment Carrageenan is a polysaccharide that can potentially hold juice solids in solution and adversely affect wine filterability. The relative filterability of wines produced after carrageenan addition to juice was assessed by juice clarification trials (Table 3). The addition of ki carrageenan to grape juice reduced the filterability of the resulting wine (C2) tenfold compared to that of the untreated Control wine (C1).

Enzyme addition to carrageenan-treated wine, including pectinase (T3) and the blend of endo- $\beta$-glucanase and cellulase (E2) enzymes in conjunction with pectinase (T2), significantly improved filtration compared to that of the Controls. Pectinase addition (T3) also improved the heat stability of the wine compared to the carrageenan-treated Control wine although the enzyme mixture (T2) reduced heat stability and increased haze. The cause of this haze is unclear and warrants further investigation. The use of a chitosan-based clarification agent (T1) improved wine heat stability compared to that of the Control wines although filterability was adversely affected. These results indicated that clarification of juice 
with pectinase addition prior to carrageenan treatment will improve wine filterability. Sensory analysis using the triangle test indicated that there was a significant $(P<0.05)$ difference between wines produced using carrageenan treatment alone or carrageenan treatment with pectinase addition (data not shown). This difference, though not necessarily negative, was taken into consideration for the large-scale trials.

\section{Influence of carrageenan structure and addition time on winemaking and filterability}

Large-scale heat stability trials were conducted to assess the effect of carrageenans added to juice, during either fermentation or to wine, on winemaking processes and wine characteristics including filterability and heat stability. Treated wines were compared to an unfined wine as a negative Control, and a bentonite-fined wine as a positive Control (Table 4). The required dose rate for addition during winemaking depended on the time of addition (Table 4). Generally, additions to juice or during fermentation were lower than those added to wine which may be due to difficulties in determining accurate heat test results in grape juices as the reverse has been noted for bentonite additions (Pocock et al. 2011). The amount of carrageenan required for the ferment additions was considered the same as for juice additions. Carrageenan addition increased the time of fermentation by approximately 1 day when added to juice and by around 2 days when added during fermentation compared to the untreated and bentonite Control wines (Table 4). A previous investigation reported that the presence of carrageenan could reduce the fermentation time (Marangon et al. 2012) although that was not observed in this case.

Wine lees were measured following the racking after cold stabilisation to determine the efficacy of carrageenan in wine recovery as compared with the bentonite and untreated 
Control wines (Table 4). The addition of $k \mathrm{~N}$ to the ferment generated around half the lees volume generated by bentonite. Wine recovery is one of the main reasons cited for finding an alternative to bentonite (Majewski et al. 2011). Improved wine recovery relative to bentonite is necessary for the adoption of carrageenans, which are more expensive fining agents compared to bentonite. These results indicated that $k \mathrm{~N}$ carrageenan addition during fermentation can provide better wine recovery than bentonite for wines produced from clarified juice. Other carrageenan additions produced a similar volume of lees as the bentonite and untreated Control wines. Unlike bentonite, carrageenans tend to float rather than settle when added to clear wine (Figure S4), however, mixing carrageenan to juice or during fermentation will cause the carrageenan to settle for efficient racking and filtration. Therefore carrageenan is best added at stages in winemaking that already generate lees for more effective settling and removal. The potential for carrageenans to facilitate a dual role of a clarification agent in aiding flotation and heat stabilisation should also be explored. Wine turbidity, the measure of wine clarity prior to filtration, was generally not significantly altered by carrageenan addition to wine compared to that of the untreated Controls. The exception was $k i$ addition, which increased wine turbidity but not to an extent that filterability was negatively influenced. Carrageenan addition during fermentation reduced wine turbidity to a similar extent as bentonite, indicating that the carrageenan lees had completely settled, and addition under these circumstances was as effective as bentonite in clarifying wines (Table 4). The addition of both $\mathrm{K}^{+}$and $\mathrm{Na}^{+}$kappa-carrageenan to wine produced similar turbidity to that of the untreated Control wine post-racking whereas addition of $k i$-carrageenan to wine 
almost doubled the turbidity. This suggested that adding carrageenan during fermentation is a more effective strategy to reduce lees production and to improve wine clarity.

The impact on wine filterability of carrageenan addition at different stages of winemaking was also assessed prior to $0.45 \mu \mathrm{m}$ filtration and bottling (Table 4). Carrageenan addition to juice or during fermentation reduced filterability in Wine 1 with filterability indices $\left(\mathrm{FI}_{\mathrm{T}}\right)>2$, suggesting potential filtration issues. Carrageenan addition to wine, however, did not negatively impact filterability. The cause of the poor wine filterability after carrageenan addition was investigated further using SEM analysis of the $0.45 \mu \mathrm{m}$ membranes (Figure 1). After filtering $k \mathrm{~N}$ wines, membranes showed strands of polymeric material filling the regular membrane pores of the filters for $k \mathrm{~N}-\mathrm{J}$ and $k \mathrm{~N}-\mathrm{F}$ (Figure 1a,b, respectively). These strands were absent from $k \mathrm{~N}-\mathrm{W}$ wines and the bentonite-treated wines (Figure 1c,d, respectively). This suggested that the poor filterability may be due to an interaction between juice or ferment solids and the carrageenan polysaccharides which prevented adequate settling. A previous study also indicated that carrageenan addition to wines can reduce filterability (Marangon et al. 2013). To avoid further filterability problems, juice for Wine 2 was first treated with pectinase which was demonstrated in the preliminary clarification trials to be effective in preventing filterability issues. Pectinase promotes the cold settling of juice and therefore was likely to improve wine clarity and filterability (Sieiro et al. 2012). All wines treated with pectinase prior to carrageenan addition and subsequent cross-flow filtration (nominal $0.4 \mu \mathrm{m}$ ) passed the filterability test (absolute pore size $0.45 \mu \mathrm{m}$ ) (Table 4). 


\section{Influence of carrageenan structure and addition time on wine heat stability}

The addition of each selected carrageenan to either juice, ferment or wine removed about $90 \%$ of the proteins present in the treated wines compared to that of the untreated Control wines (Figure 2). The proportion of protein removed from the wines was greater after filtration and bottling, suggesting that some of the protein-absorbed carrageenan is removed with filtration. Protein concentration in carrageenan-treated wines after filtering and bottling (Table 5) was marginally greater than the protein concentration in wines treated with bentonite. This reduction in protein contributed to the heat stability of most of the treated wines (Table 5). The only treated wines that were not heat stable were the addition of $k \mathrm{~N}, k \mathrm{~K}$ and $k i$ carrageenan to juice for Wine 2 with one or more replicates producing $>2.0 \Delta \mathrm{NTU}$ in the heat test which was higher than the $\leq 2.0 \Delta \mathrm{NTU}$ required to pass the test. This may relate to the difficulty in determining the heat stability of grape juice. After bottling, wines were stored under cellar conditions $\left(16^{\circ} \mathrm{C}\right)$ and the heat stability of the wines was measured at 13 months for Wine 2 and 13 and 25 months for Wine 1 (Table 5). Wines with either carrageenan or bentonite treatment that were heat stable at bottling remained heat stable with storage, while the untreated Control wines were not stable. This indicated the long-term effectiveness of carrageenan treatment.

\section{Influence of carrageenan structure and addition time on wine composition}

Cations are known to play a part in the gelation of carrageenans and therefore the different metal ions present in juice and wine are likely to influence carrageenan rheology and viscosity ( Leske et al. 1997, Campo et al. 2009). The concentration of metals in wine is also important due to limits for wine exports as well as influencing metal-complex instabilities. 
The addition of carrageenans containing either $\mathrm{Na}^{+}$or $\mathrm{K}^{+}$ions was also likely to influence the concentration of these ions in each wine (Figure 3). Adding $k \mathrm{~N}$-carrageenan, which contained $55 \mathrm{mg} / \mathrm{g}$ sodium (Table 2), increased the $\mathrm{Na}^{+}$concentration of the wine fourfold compared to that of the Control wine (Figure 3a). The level of $\mathrm{Na}^{+}$present in the $k \mathrm{~N}$ wines was greater than the $60 \mathrm{mg} / \mathrm{L}$ recommended maximum for export to Switzerland (de Loryn et al. 2014). Such increase in $\mathrm{Na}^{+}$concentration may prevent the commercial use of $k \mathrm{~N}$ in export wines. The addition of $\mathrm{K}^{+}$-dominant carrageenan, $k \mathrm{~K}$, however, did not significantly increase the concentration of $\mathrm{K}^{+}$in the wines (Figure $3 \mathrm{~b}$ ). Potassium is the most abundant metal in wine and is a strong gelation agent for kappa-carrageenans ( Leske et al. 1997, Campo et al. 2009). The concentration of calcium ions in Wine 2 with following addition of $k i$ and $k \mathrm{~K}$ carrageenan was significantly higher than that in the $k \mathrm{~N}$-treated wines (Figure $3 \mathrm{c}$ ), although the concentration of calcium ions in the carrageenan product was low (Table 2). $\mathrm{A} \mathrm{Ca}^{2+}$ concentration above $120 \mathrm{mg} / \mathrm{L}$ in wine may present a risk for $\mathrm{Ca}^{2+}$ tartrate instability (McKinnon et al. 1995). The concentration of copper, iron, manganese, zinc and magnesium (Table 6) was not altered by the addition of carrageenans at any winemaking stage to a level that would be detrimental to either wine quality or metal instability. Wine chemical analysis (Table 6) also indicated that the addition of carrageenan and the delay in fermentation did not significantly impact the basic wine parameters of alcohol, $\mathrm{pH}$, TA and VA for each wine. Influence of carrageenan structure and addition time on wine sensory profiles For the large-scale trials, descriptive sensory analysis was conducted for Wine 1 and Wine 2 after 4 months bottle-ageing to determine the impact of carrageenan addition at different stages of winemaking on the sensory characteristics of the wine. For Wine 1, eight of the 27 
sensory attributes (Table 1$)$ differed significantly $(P<0.05)$ due to carrageenan type and addition time compared with a bentonite Control: yellow colour intensity, passionfruit, floral, box hedge, sweaty/cheesy, viscosity, astringency and bitterness (Figure 4). In addition, the attributes flint and pungent were found to be different at a low level of significance $(P \leq$ 0.10). Carrageenan-treated wines and untreated Control wines rated higher in flavour and aroma intensity and yellow intensity than wines treated with bentonite (Figure 4a). The sensory characteristics of wines treated with $\mathrm{kN}$ carrageenan did not vary widely with addition time and were similar in sensory profiles to the untreated Control wines, whereas the time of addition influenced sensory profiles for wines treated with ki carrageenans (Figure 4b). For ki carrageenan, addition to juice resulted in wines with more box hedge character, whereas addition to wine produced more floral character. Ferment addition of ki resulted in more pungent and bitter wines. Bentonite addition to wine consistently showed a reduction in the flavour and aroma intensity of these wines. Wine 2 with $k \mathrm{~K}$ carrageenan added at different stages of winemaking yielded ten significant attributes: yellow colour intensity, stone fruit aroma, floral, vegetal, pungent, stone fruit flavour, apple flavour, green flavour, bitter and fruit aftertaste (Figure 5). Addition of $k \mathrm{~K}$ to wine produced more stone fruit aroma and flavour and were less bitter than the Control wines (Figure 5a). Bentonite-treated wines were less yellow and had a lower intensity of fruity aromas than the carrageenan-treated or untreated Control wines. Principle component analysis (PCA) also demonstrated substantial differences in wine sensory profiles with carrageenan addition time (Figure 5b). Addition of $k \mathrm{~K}$ to Wine 2 during fermentation induced more bitter and green characters in the wine compared to addition to wine or juice. These results demonstrated that carrageenans added to 
wine produce more fruity or floral characters than carrageenans added during fermentation or to juice.

\section{Conclusions}

Kappa-carrageenans have demonstrated a capability to produce heat-stable wine without increasing wine lees or wine turbidity. Kappa-carrageenan with $\mathrm{K}^{+}$ions added to wine was the most effective treatment for producing heat-stable wine with minimal impact on sensory profiles, wine lees, turbidity, filterability and concentration of metal ions compared to untreated Control wines. Sensory analysis also indicated that wines heat-stabilised with carrageenans had more intense flavour and aroma profiles than those heat-stabilised with bentonite. Juice clarification with pectinase substantially improved the filterability of all wines treated with carrageenan. The potential for carrageenans to facilitate a dual role as a clarification agent in aiding flotation and as a heat-stabilising agent should be further explored given the flotation properties of carrageenans. The results from this study demonstrated that kappa-carrageenan, a renewable fining agent, can be used to heat stabilise wines and may become a useful alternative to bentonite.

\section{Acknowledgments}

The authors would like to thank Treasury Wine Estates for donating the juice and CP-Kelco, Cargill, Herbstreith \& Fox and IMCD for donating polysaccharides and ongoing support. We would also like to acknowledge the contribution of the Wine Innovation Cluster (WIC), a pilot winery for small-scale winemaking, with particular acknowledgment to winemakers $\mathrm{Mr}$ Michael Coode and Mr John Gledhill. We would also like to thank The Australian Wine Research Institute (AWRI) sensory panellists, Dr Leigh Francis and Ms Alice Barker for their 
contributions for the sensory descriptive analysis data, Mr Neil Scrimgeour for assistance in sensory coordination, Ms Kate Cuijvers for filterability analyses and the AWRI Commercial Services team for analysis of wine composition. This project was supported by funds from Wine Australia, Grant No: TWE 1301 to Treasury Wine Estates.

\section{References}

Alba, K. and Kontogiorgos, V. (2018) Seaweed polysaccarides (agar, alginate, carrageenan). Varelis, P., Melton, L. and Shahidi, F., eds . Encyclopedia of food chemistry (Elsevier: Amsterdam, The Netherlands).

BH Technologies (2015) Manual filterability test procedure (BH Technologies: Grenoble, France).

Cabello-Pasini, A., Victoria-Cota, N., Macias-Carranza, V., Hernandez-Garibay, E. and, Muniz-Salazar, R. (2005) Clarification of wines using polysaccharides extracted from seaweeds. American Journal of Enology and Viticulture 56, 52-59.

Campo, V.L., Kawano, D.F., da Silva, D.B.J. and Carvalho, I. (2009) Carrageenans: biological properties, chemical modifications and structural analysis: a review. Carbohydrate Polymers77, 167-180.

Craigie, J., Wen Z,C. and van der Meer, J.P. (1984) Interspecific, intraspecific and nutritionally-determined variations in the composition of agars from Gracilaria spp. Botanica Marina 27(2), 55-62. • 
de Loryn, L.C., Petrie, P. R., Hasted, A.M., Johnson, T.E., Collins, C. and Bastian, S.E.P. (2014) Evaluation of sensory thresholds and perception of sodium chloride in grape juice and wine. American Journal of Enology and Viticulture 65,124-133.

Dordoni, R., Colangelo, D., Giribaldi, M., Giuffrida, G., De Faveri, D.M. and Lambri, M. (2015) Effect of bentonite characteristics on wine proteins, polyphenols, and metals under different pH conditions. American Journal of Enology and Viticulture 66, 518-530.

Duan, W., Giandinoto, C., Goldsmith, M., Hosking, P., Lentini, A., Oliver, T., Rogers, P., Smith, P., Bacic, A. and Liao, M.-L. (2006) Methods and compositions for fining beverages. Patent WO 2006/032088.

Food Standards Australia New Zealand (2017) A1126 Pectins and carrageenans as processing aids in wine (fining agent) (Food Standards Australia New Zealand: Canberra, ACT, Australia) http://www.foodstandards.gov.au/code/applications/Pages/A1126PectinsCarrageenan-asPAs.aspx Food Standards Australia and New Zealand.

Iland, P.G., Bruer, N., Ewart, A., Markides, A. and Sitters, J. (2012) Monitoring the winemaking process from grapes to wine: techniques and concepts. 2d ed. (Patrick Iland Wine Promotions: Campbelltown, SA, Australia) pp. 86-87.

Janaswamy, S. and Chandrasekaran, R. (2002) Effect of calcium ions on the organization of iota-carrageenan helices: an X-ray investigation. Carbohydrate Research 337, 523-535.

Kara, S., Arda, E., Kavzak, B. and Pekcan, O. (2006) Phase transitions of K-carrageenan gels in various types of salts. Journal of Applied Polymer Science 102, 3008-3016. 
Lambri, M., Dordoni, R., Silva, A. and De Faveri, D.M. (2013) Odor-active compound adsorption onto bentonite in a model white wine solution. Chemical Engineering Transactions 32, 1741-1746.

Leske, P.A., Sas, A.N., Coulter, A.D., Stockley, C.S. and Lee, T.H. (1997) The composition of Australian grape juice: chloride, sodium and sulfate ions. Australian Journal of Grape and Wine Research 3, 26-30.

Majewski, P., Barbalet, A. and Waters, E.J. (2011) \$1 billion hidden cost of bentonite fining. Australian \& New Zealand Grapegrower \& Winemaker (569), 58-59,61-62.

Marangon, M., Lucchetta, M., Duan, D., Stockdale, V.J., Hart, A., Rogers, P.J. and Waters, E.J. (2012) Protein removal from a Chardonnay juice by addition of carrageenan and pectin. Australian Journal of Grape and Wine Research 18, 194-202.

Marangon, M., Stockdale, V.J., Munro, P., Trethewey, T., Schulkin, A., Holt, H.E. and Smith, P.A. (2013) Addition of carrageenan at different stages of winemaking for white wine protein stabilization. Journal of Agricultural and Food Chemistry 61, 6516-6524.

McKinnon, A.J., Scollary, G.R., Solomon, D.H. and Williams, P.J. (1995) The influence of wine components on the spontaneous precipitation of calcium $\mathrm{L}(+)$-tartrate in a model wine solution. American Journal of Enology and Viticulture 46, 509-517.

McRae, J.M., Barricklow, V., Pocock, K.F. and Smith, P.A. (2018) Predicting protein haze formation in white wines. Australian Journal for Grape and Wine Research 24, 504-511. McRae, J.M., Mierczynska-Vasilev, A., Soden, A., Barker, A.M., Day, M.P. and Smith, P.A. (2017) Effect of commercial-scale filtration on sensory and colloidal properties of red wines over18 months bottle aging. American Journal of Enology and Viticulture 68, 263 - 274. 
Muhlack, R.A., O'Neill, B.K. and Colby, C.B. (2016) Optimal conditions for controlling haze-forming wine protein with bentonite treatment: investigating matrix effects and interactions using a factorial design. Food Bioprocess Technology 9, 936-943.

Muhlack, R., Nordestgaard, S., Waters, E.J., O'Neill, B.K., Lim, A. and Colby, C.B. (2006) In-line dosing for bentonite fining of wine or juice: contact time, clarification, product recovery and sensory effects. Australian Journal of Grape and Wine Research 12, 221-234. Necas, J. and Bartosikoya, L. (2013) Carrageenan: a review. Veterinari Medicina 58, 187205.

Pocock, K., Salazar, F.N. and Waters, E.J. (2011) The effect of bentonite fining at different stages of white winemaking on protein stability. Australian Journal of Grape and Wine Research 17, 280-284.

Standards Association of Australia (1988) Sensory analysis of foods - specific methods triangle Test AS 2542.2 (Standards Association of Australia: North Ryde, NSW, Australia) pp.1-15.

Siebert, T.E., Barker, A.M., Pearson, W.B., S.R., de Barros Lopes, M.A., Darriet, P., Herderich, M.J. and Francis, I.L. (2018) Volatile compounds related to 'stone fruit' aroma attributes in Viognier and Chardonnay wines. Journal of Agricultural and Food Chemistry 66, 2838-2850

Sieiro, C., García-Fraga, B., López-Seijas, J., da Silva, A. and Villa, T. (2012) Microbial pectic enzymes in the food and wine industry. Valdez, B., ed. Food industrial processes methods and equipment (IntechOpen: London, England). 
Stevenson, T.T., and Fumeaux R.H. (1991) Chemical methods for the analysis of sulfated galactans from red algae. Carbohydrate Research 210 277-98

Tattersall, D.B., van Heeswijck, R. and Hoj, P.B. 1997. Identification and characterization of a fruit-specific, thaumatin-like protein that accumulates at very high levels in conjunction with the onset of sugar accumulation and berry softening in grapes. Plant Physiology 114, 759-769.

Trudsoe, J. (2010) Carrageenan modified by ion-exchange process.Patent Application US12/403,097. pp.1-16.

Van de Velde, F., Knutsen, S.H., Usov, A.I., Rollema, H.S. and Cerezo, A.S. (2002) 1H and 13C high resolution NMR spectroscopy of carrageenan: application in research and industry. Trends in Food Science and Technology 13, 73-92.

Van Sluyter, S.C., McRae, J.M., Falconer, R.J., Smith, P.A., Bacic, A., Waters, E.J. and Marangon, M. (2015) Wine protein haze: mechanisms of formation and advances in prevention. Journal of Agricultural and Food Chemistry 63, 4020-4030.

Vincenzi, S., Marangon, M., Tolin, S. and Curioni, A. (2011) Protein evolution during the early stages of white winemaking and its relations with wine stability. Australian Journal of Grape and Wine Research 17, 20-27.

Vincenzi, S., Panighel, A., Gazzola, D., Flamini, R. and Courioni, A. (2015) Study of combined effect of proteins and bentonite fining on the wine aroma loss. Journal of Agricultural and Food Chemsitry 63, 2314-2320. 
Waters, E.J., Alexander, G., Muhlack, R., Pocock, K.F., Colby, C., O'Neill, B.K., Hoj, P.B. and Jones, P. (2005) Preventing protein haze in bottled white wine. Australian Journal of Grape and Wine Research 11, 215-225.

Wilson, S.M. and Bacic, A. (2012) Preparation of plant cells for transmission electron microscopy to optimize immunogold labeling of carbohydrate and protein epitopes. Nature Protocols 7, 1716-1727. 


\section{Figure captions}

Figure 1. Scanning electron micrographs (35 000x) of filter membranes after filtering Wine 1 containing kappa-carrageenan $(k \mathrm{~N})$ added at different winemaking stages. (a) juice addition [kN-J, filterability index $\left.\left(\mathrm{FI}_{\mathrm{T}}\right)=7 \pm 4\right]$; (b) ferment addition $\left(k N-F, \mathrm{FI}_{\mathrm{T}}=16 \pm 13\right)$; (c) wine addition $\left(k \mathrm{~N}-\mathrm{W}, \mathrm{FI}_{\mathrm{T}}=1 \pm 0\right)$; and $(\mathrm{d})$ bentonite Control $\left(\mathrm{FI}_{\mathrm{T}}=1 \pm 0\right)$.

Figure 2. Proportion of protein removed by carrageenan treatment pre-bottling ( $\mathbf{\square}$ ) (and postbottling ( $\boldsymbol{\square}$ ) of (a) Wine 1; and (b) Wine 2 when added at different stages of winemaking compared to the untreated Control wines. Results are shown as the average of triplicate ferments \pm one SD. Dash line represents $90 \%$ protein removal. Bent, bentonite; $k \mathrm{~N}-\mathrm{J}, \mathrm{kappa-}$ carrageenan with sodium ion, juice addition ; $k \mathrm{~N}-\mathrm{F}$, kappa-carrageenan with sodium ion, ferment addition; kN-W, kappa-carrageenan with sodium ion, wine addition; ki-J, kappaiota carrageenan blended juice addition; ki-F, kappa-iota carrageenan blended ferment addition; ki-W, kappa-iota carrageenan blended wine addition; kK-J, kappa-carrageenan with potassium ion, juice addition; kK-F, kappa-carrageenan with potassium ion, ferment addition; $k \mathrm{~K}-\mathrm{W}$, kappa-carrageenan with potassium ion, wine addition;

Figure 3. Concentration of (a) sodium ions, (b) potasium ions and (c) calcium ions in Wine 1 and Wine 2 after addition of heat-stabilising agents including Control ( $\boldsymbol{\square})$, bentonite ( $\boldsymbol{\square})$, kappa-carrageenan with sodium ions $(k \mathrm{~N})(\mathbf{\square})$, kappa-iota carrageenan blend $(k i)(\boldsymbol{\square})$ and

This article is protected by copyright. All rights reserved. 
kappa-carrageenan with potassium ions $(k \mathrm{~K})(\mathbf{\square})$. Results are shown as the average of different treatment times \pm one SD.

Figure 4. Sensory analysis for Wine 1 presented as (a) Spider plot and (b) Scores and loadings bi-plot for principal component analysis of sensory attributes that varied significantly with carrageenan type or addition time for heat-stabilised wines and untreated Control wines. Spell out treatment abbreviations, i.e. kiK FA

Figure 5. Sensory analysis for Wine 2 presented as (a) Spider plot and (b) Scores and loadings bi-plot for principal component analysis of sensory attributes that varied significantly with carrageenan type or addition time for heat-stabilised wines and untreated Control wines.

\section{Supporting data}

Table S1. Properties of the selected carrageenan samples for large-scale trials.

Table S2. Proton $\left({ }^{1} \mathrm{H}\right)$ NMR chemical shifts for the main structural units of commercial carrageenans.

Figure S1. Schematic representation of the preliminary clarification trials showing type of clarification agent and addition stages for each treatment.

Figure S2. Schematic representation of the pilot scale winemaking process and points for addition of fining agents as described in the materials and methods section.

Figure S3. ${ }^{1} \mathrm{H}$ NMR spectra of (a) $\kappa$-/l- (blended) carrageenan and (b) $\kappa$-carrageenan. 
Figure S4. Wines treated with heat stabilising agents after $96 \mathrm{~h}$ settling at $4^{\circ} \mathrm{C}$. Each solution was mixed with a homogeniser for 2 min before transferring to a glass measuring cylinder.

(a) 0.8 g/L bentonite; (b) $1.0 \mathrm{~g} / \mathrm{L}$ kappa-carrageenan; (c) $1.5 \mathrm{~g} / \mathrm{L}$ kappa-carrageenan. 


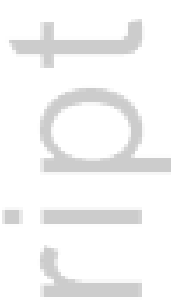

Figure 1. Scanning electron micrographs $(35,000 x)$ of filter

membranes after filtering Wine 1 containing kappa-carrageenan

$(\mathrm{kN})$ added at different winemaking stages. a) juice addition $(\mathrm{kN}$ -

$J, F I=7 \pm 4)$; b) ferment addition $(k N-F, F I=16 \pm 13)$; c) wine

addition ( $(\mathrm{N}-\mathrm{W}, \mathrm{Fl}=1 \pm 0)$; d) bentonite control $(\mathrm{Fl}=1 \pm 0$ ).

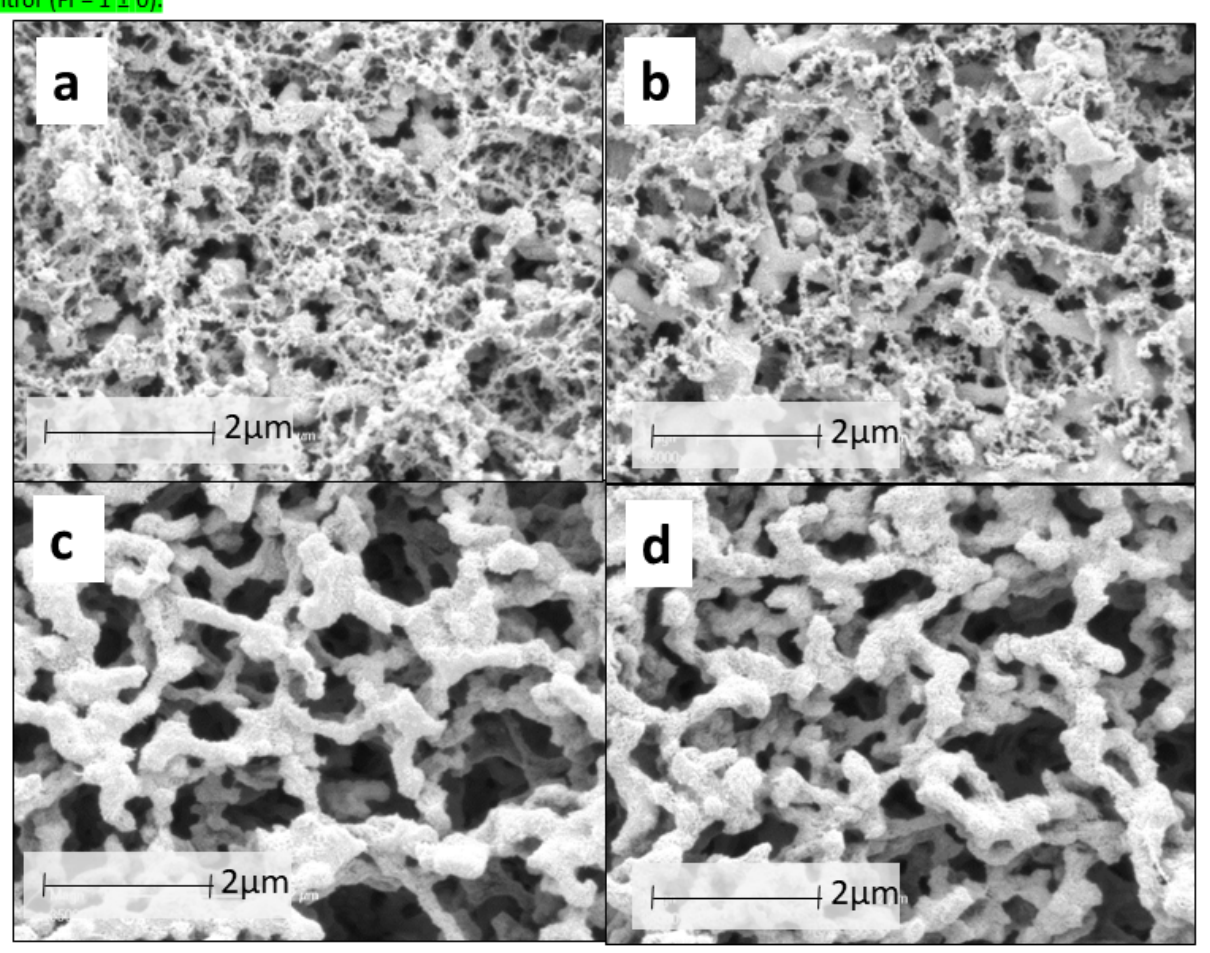

AJGW_12411_Figure 1_TL edit (002).tif 


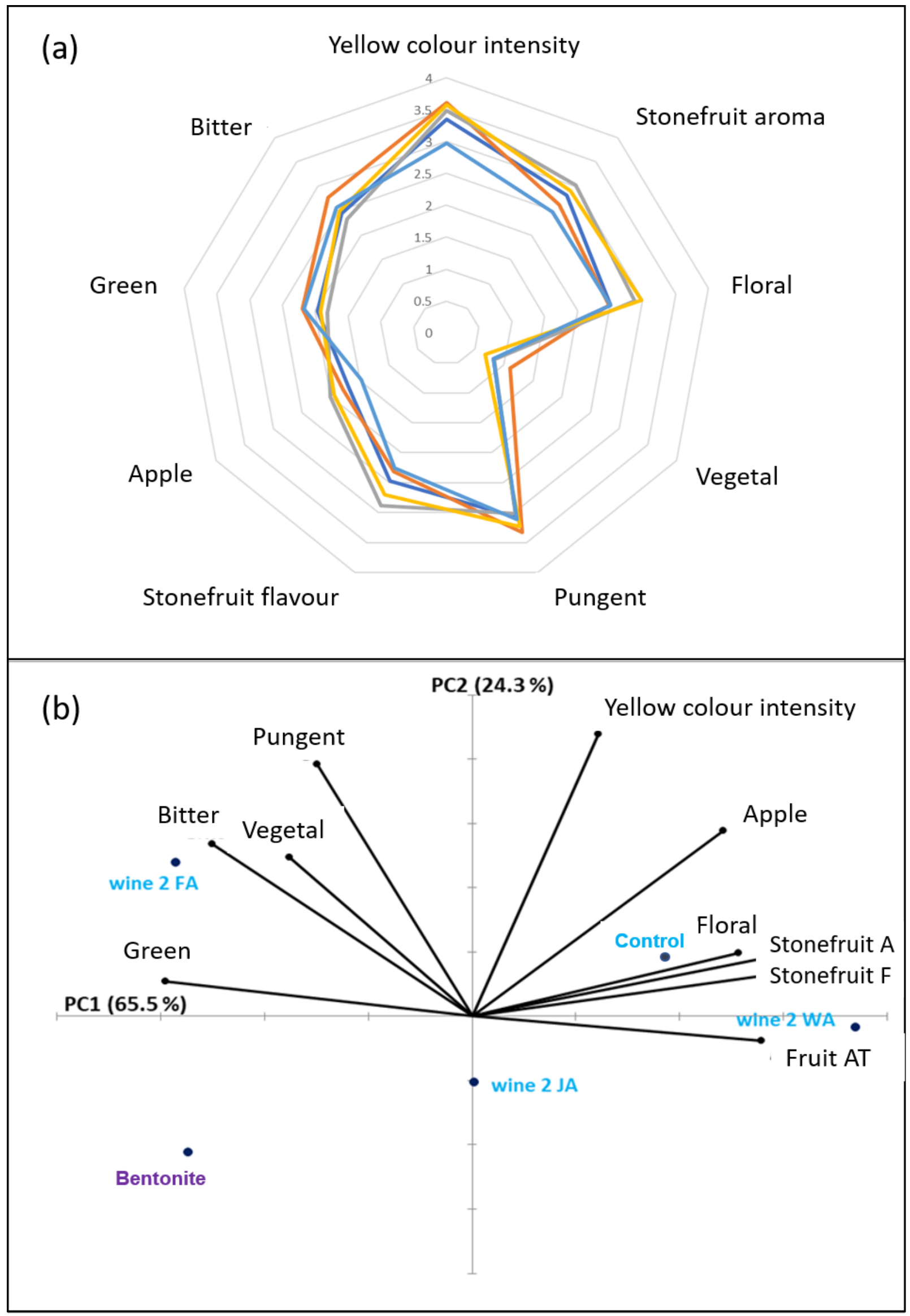

AJGW_12411_Figure 5_TL edit (002).tif

This article is protected by copyright. All rights reserved. 


\section{Supporting information}

2 Table S1. Properties of the selected carrageenan samples for large-scale trials.

\begin{tabular}{llllll}
\hline Code & Name & Structures & Metal ion & Batch No. & Year \\
\hline$k \mathrm{~N}$ & Kappa & $\begin{array}{l}\text { Kappa- } \\
\text { carrageenan }\end{array}$ & $\mathrm{Na}^{+}$ & A-533, A-980 & 2014,2015 \\
$k i$ & $\begin{array}{l}\text { Kappa/iota } \\
\text { blended }\end{array}$ & $\begin{array}{l}90 \% \\
\text { Kappa, } \\
10 \% \text { iota }\end{array}$ & $\mathrm{Na}^{+} / \mathrm{K}^{+}$ & B-2, B-3 & 2014,2015 \\
& Kappa & $\begin{array}{l}\text { Kappa- } \\
\text { carrageenan }\end{array}$ & $\mathrm{K}^{+}$ & A-978 & \\
$k \mathrm{~K}$ & & & 2015 \\
\end{tabular}

$3{ }^{\dagger}$ Kappa- and iota- carrageenans can occur in the same carrageenan chain (hybrid) or as a

4 blend (blended) of different kappa- and iota- carrageenans; ${ }^{\ddagger} 94 \%$ kappa- and $6 \%$ iota-

5 carrageenans by polysaccharide linkage analysis.

6 
8 Table S2. Proton $\left({ }^{1} \mathrm{H}\right)$ NMR chemical shifts for the main structural units of commercial

9 carrageenans.

\begin{tabular}{|c|c|c|c|c|c|c|c|c|}
\hline \multirow{2}{*}{$\begin{array}{l}\text { Carrageenan } \\
\text { type }\end{array}$} & \multirow[t]{2}{*}{ Unit } & \multirow{2}{*}{$\begin{array}{l}\text { Sugar } \\
\text { (Galp) }\end{array}$} & \multicolumn{6}{|c|}{ 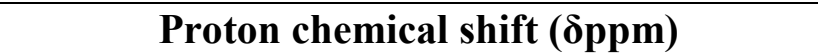 } \\
\hline & & & H-1 & H-2 & $\mathbf{H}-3$ & H-4 & H-5 & H-6 \\
\hline \multirow[t]{2}{*}{$\kappa-$} & G4S & 3-linked & 4.70 & 3.68 & 4.15 & 4.94 & 3.89 & 3.89 \\
\hline & DA & 4-linked & 5.17 & 4.22 & 4.61 & 4.73 & 4.68 & $4.30 / 4.16$ \\
\hline \multirow[t]{2}{*}{$l-$} & G4S & 3-linked & 4.77 & 3.71 & 4.18 & 4.95 & 3.90 & 3.90 \\
\hline & DA2S & 4-linked & 5.35 & 4.77 & 4.86 & 4.78 & 4.78 & $4.53 / 4.21$ \\
\hline$\lambda-$ & D2S,6S & 4-linked & 5.59 & - & - & - & - & - \\
\hline$\mu-$ & D6S & 4-linked & 5.26 & - & - & - & - & - \\
\hline$v-$ & D2S,6S & 4-linked & 5.52 & - & - & - & - & - \\
\hline
\end{tabular}

10 DA-unit, 3,6-anhydro- $\alpha$-D-Galp; G, 1,3-linked- $\beta$ - D-Galp; $\kappa$-, kappa; $\iota$-, iota; $\lambda$-, lambda; $\mu$-, $11 \quad m u ; v$-, $n u ; p$, pyranose; $\mathrm{S}$, sulfate ester groups. 


\section{Tables}

Table 1. Sensory descriptive analysis attributes, definitions and standards.

\begin{tabular}{|c|c|c|}
\hline Attribute & Definition/synonyms & Standard \\
\hline $\begin{array}{l}\text { Appearance } \\
\text { Yellow colour } \\
\text { intensity }\end{array}$ & Intensity of the yellow colour & \\
\hline $\begin{array}{l}\text { Aroma } \\
\text { Overall fruit } \\
\text { intensity aroma }\end{array}$ & Intensity of the fruit aromas in the sample & \\
\hline Passionfruit & Intensity of the aroma of passionfruit & $\begin{array}{l}1 \text { tsp Passionfruit } \\
\text { pulp (John West) }\end{array}$ \\
\hline Pineapple & Intensity of the aroma of pineapple & $\begin{array}{l}4 \text { x } 2 \text { cm Cubes } \\
\text { fresh pineapple, } \\
\text { canned pineapple } \\
\text { juice ( } 1 \text { tsp, } \\
\text { Golden Circle) }\end{array}$ \\
\hline Stone fruit & $\begin{array}{l}\text { Intensity of the aroma of stone fruits: peach, apricot } \\
\text { both fresh and dried, loquat }\end{array}$ & $\begin{array}{l}1 \text { Can of Goulburn } \\
\text { Valley apricots } \\
\text { and peaches }\end{array}$ \\
\hline Lemon & Intensity of the aroma of lemon & $\begin{array}{l}1 \times 2 \mathrm{~cm} \text { Piece of } \\
\text { lemon, lemon rind }\end{array}$ \\
\hline
\end{tabular}

Confection Intensity of the aroma of confection: banana lolly, musk $1 \mathrm{x}$ Banana lolly and 1 x musk lolly

Floral

Intensity of the aroma of flowers: violets and blossoms

$100 \mathrm{mg} / \mathrm{L}$ Linalool $(40 \mu \mathrm{L}), 200 \mathrm{mg} / \mathrm{L}$ 2-phenyl ethanol $(25 \mu \mathrm{L})$

Green Intensity of the aroma of green grass, green leaves, Freshly picked stalks, green capsicum, green beans grass and half a chopped fresh green bean

Box hedge Intensity of the aroma of box hedge Fresh box leaves

Flint Intensity of the aroma of flint, wet stones, metals, toast $20 \mu \mathrm{L}$ of $1 \mathrm{mg} / \mathrm{L}$ Benzyl mercaptan

Sweaty/Cheesy Intensity of the aroma of sweat, cheese, blue cheese, $100 \mu \mathrm{L}$ Mix of cheddar cheese, body odour, sour milk, raw meat hexanoic acid and isovaleric acid 
Pungent Intensity of the aroma and effect of alcohol

\section{Palate}

Overall fruit Intensity of the fruit flavours in the sample

intensity palate

Tropical Intensity of the flavour of tropical fruits; pineapple, passionfruit, melon

Stone fruit Intensity of the flavour of stone fruits; peach, apricot, nectarine

Lemon Intensity of the flavour of lemon including aftertaste

Green apple Intensity of the flavour of green apple including aftertaste

Green Intensity of the flavour of green grass, green capsicum, stalks, herbal

Viscosity The perception of the body, weight or thickness of the wine in the mouth. Low, watery, thin mouth feel; high, thick mouth feel

Oily The perception of oiliness in the mouth

Sweet Intensity of sweet taste in the mouth including aftertaste

Acid Intensity of acid taste in the mouth including aftertaste

Hotness The intensity of alcohol hotness perceived in the mouth, after expectoration and the associated burning sensation; low, warm; high, hot

Astringency The drying and mouth-puckering sensation in the mouth; low, coating teeth; medium, mouth coating and drying; high, puckering, lasting astringency

Bitter The intensity of bitter taste perceived in the mouth, or after expectoration

Fruit after taste The lingering tropical or stone fruit flavour perceived in the mouth after expectorating 
Table 2. Composition of different batches of carrageenans, including type, carbohydrate concentration and cation concentration (provided by suppliers), as well as the relative solubility in water and in wine and the heat stability of a Chardonnay wine after treatment with each carrageenan at the stated dose.

\begin{tabular}{|c|c|c|c|c|c|c|c|c|c|}
\hline \multirow[t]{2}{*}{ Type } & \multirow[t]{2}{*}{$\begin{array}{l}\text { Batch } \\
\text { No. } \dagger\end{array}$} & \multirow[t]{2}{*}{$\begin{array}{c}\text { CHO } \\
(\%)\end{array}$} & \multirow[t]{2}{*}{$\begin{array}{c}\mathrm{K}^{+} \\
(\mathrm{mg} / \mathrm{g})\end{array}$} & \multirow[t]{2}{*}{$\begin{array}{c}\mathrm{Na}^{+} \\
(\mathrm{mg} / \mathrm{g})\end{array}$} & \multirow[t]{2}{*}{$\begin{array}{c}\mathrm{Ca}^{+} \\
(\mathrm{mg} / \mathrm{g})\end{array}$} & \multicolumn{2}{|c|}{$\begin{array}{c}\text { Viscosity } \\
\text { index }\end{array}$} & \multirow[t]{2}{*}{$\begin{array}{l}\text { Dose } \\
(\mathrm{g} / \mathrm{L})\end{array}$} & \multirow[t]{2}{*}{$\begin{array}{c}\text { Heat } \\
\Delta \text { NTU }\end{array}$} \\
\hline & & & & & & $\mathrm{H}_{2} \mathrm{O}$ & Wine & & \\
\hline$\kappa-$ & A978 & 97 & 91 & 6 & ND & 6 & 1 & 1.2 & $2.0 \pm 0.1 \ddagger$ \\
\hline$\kappa-$ & A371 & 96 & 91 & 6 & 0.05 & 6 & 1 & 1.0 & $2.2 \pm 0.2$ \\
\hline$\kappa-$ & B1R & 95 & 100 & ND & ND & 6 & 1 & 1.2 & $2.5 \pm 0.1$ \\
\hline$\kappa-$ & S1263 & ND & 26 & 16 & 33 & 6 & ND & 1.0 & $4.5 \pm 0.1$ \\
\hline$\kappa-(\mathrm{CS})$ & A533 & 98 & 1.1 & 55 & 0.9 & 4 & 3 & 1.0 & $1.8 \pm 0.2 \ddagger$ \\
\hline$\kappa-(\mathrm{CS})$ & A980 & ND & 1.1 & 55 & 0.9 & 4 & 3 & 1.2 & $3.1 \pm 0.3$ \\
\hline$\kappa-(\mathrm{SR})$ & A369 & 88 & 85 & 11 & 5 & 2 & ND & 1.0 & $50.0^{\mathrm{f}}$ \\
\hline $\begin{array}{l}\kappa-/ \iota- \\
(90: 10)\end{array}$ & B2 & 96 & 100 & ND & ND & 6 & 1 & 1.0 & $1.9 \pm 0.0 \ddagger$ \\
\hline $\begin{array}{l}\kappa-/ \iota- \\
(90: 10)\end{array}$ & B3R & 98 & 100 & ND & ND & 6 & 1 & 1.2 & $3.4 \pm 0.4$ \\
\hline $\begin{array}{l}\kappa-/ \iota- \\
(90: 10)\end{array}$ & SBe & ND & 43 & 51 & ND & 6 & ND & 1.0 & $4.4 \pm 0.65$ \\
\hline$\kappa-/ \imath-/ \lambda-$ & A532 & 96 & 23 & 63 & 1.6 & 4 & ND & 1.0 & $5.8 \pm 0.6$ \\
\hline$\lambda-$ & A529 & 96 & 14 & 57 & ND & 6 & ND & 1.0 & 12.8 \\
\hline$\lambda-$ & S3889 & - & 38 & 7 & ND & 3 & ND & 1.0 & 26.6 \\
\hline$\lambda-$ & A368 & 96 & 18 & 50 & ND & 5 & ND & 1.0 & 36.6 \\
\hline $\begin{array}{l}\lambda-/ l^{-} \\
(90: 10)\end{array}$ & SBe & ND & ND & ND & ND & 3 & ND & 1.0 & 43.6 \\
\hline$l^{-}$ & S4014 & ND & ND & ND & ND & 6 & ND & 1.0 & 22.9 \\
\hline$l-(\mathrm{SR})$ & A370 & 89 & 112 & 9 & ND & 2 & ND & 1.0 & 36.2 \\
\hline$l-/ v-$ & A367 & 98 & 43 & 51 & ND & 4 & ND & 1.0 & 17.8 \\
\hline $\begin{array}{l}l-/ v- \\
(\mathrm{CS})\end{array}$ & A372 & 97 & 6 & 80 & ND & 4 & ND & 1.0 & 30.3 \\
\hline
\end{tabular}

Heat stability of the untreated Chardonnay wine was 34.6 $\Delta$ NTU; wines with $<2.0 \Delta \mathrm{NTU}$ were considered heat-stable. Results are shown as the mean of triplicate analyses \pm one SD except where indicated. Values without SD indicate an initial NTU $>2.0$ and therefore the heat test was not repeated. †Batch numbers include the following supplier codes: A, CP 
Kelco ApS; B, Cargill Australia; S, Sigma. $\ddagger$ Heat stability results produced by the carrageenans that were selected for further trials. CHO, carbohydrate as total polysaccharide expressed as a \% (w/w); CS, cold soluble; ı-, iota-carrageenan, $\lambda$-, lambda-carrageenan; $\kappa-$, kappa-carrageenan; v-, nu-carrageenan; k-/l- (90:10), commercial blended $k$-/l- (90:10) carrageenan consists of $94.4 \% \kappa$ - and $5.6 \% l$ - carrageenans when measured by linkage analysis; ND, not determined; SR, semi-refined. 
Table 3. Effect of grape juice additives for the preliminary clarification trials on wine filterability indices before and after cross-flow filtration, and wine heat stability.

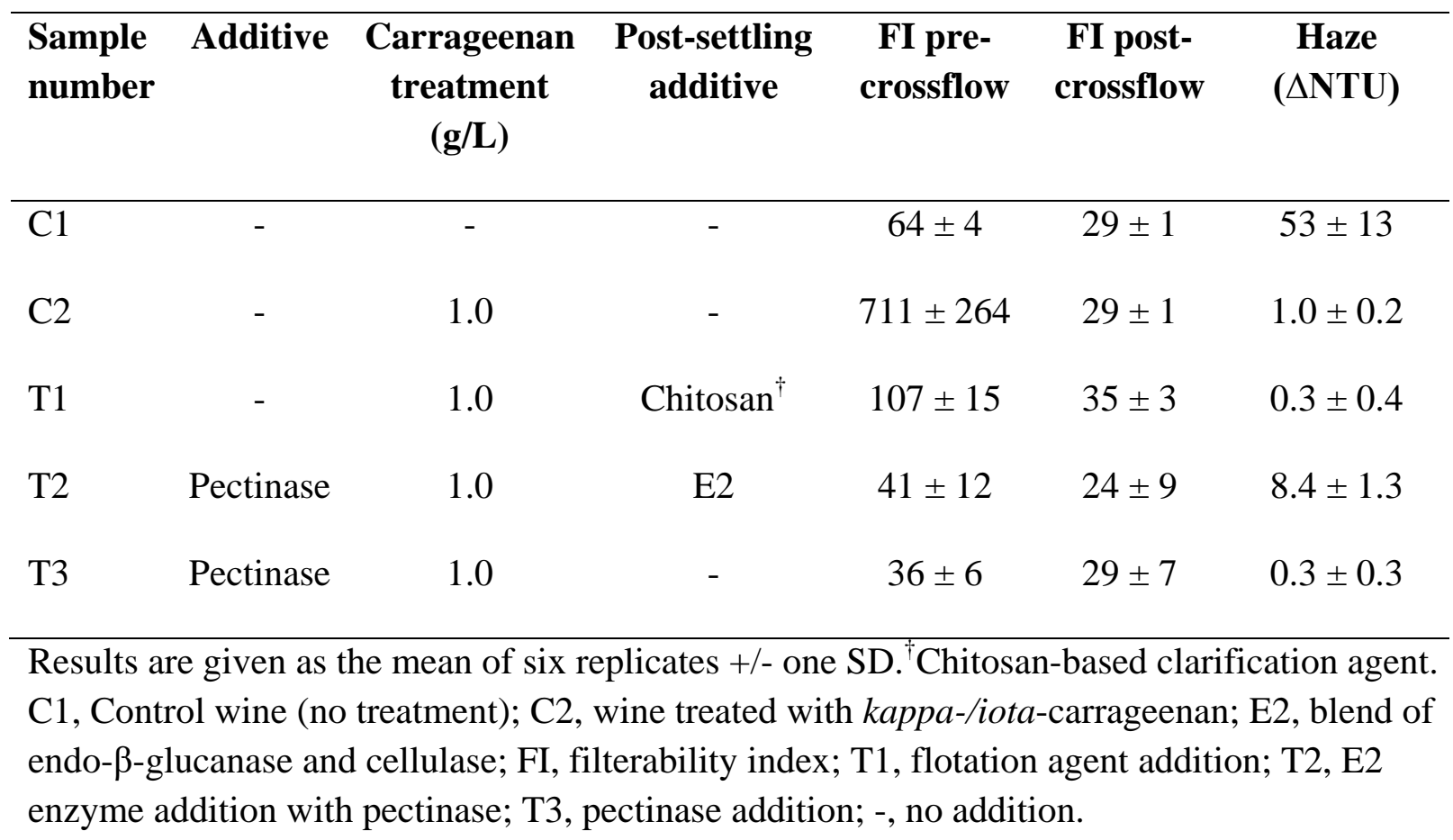


Table 4. Effect of the addition during large scale winemaking trials of carrageenans and bentonite to either juice, during fermentation or to wine on fermentation time, quantity of wine lees, wine filterability and filterability index.

\begin{tabular}{llcccccc}
\hline $\begin{array}{l}\text { Wine and } \\
\text { Treatment }\end{array}$ & $\begin{array}{l}\text { Addition } \\
\text { time } \dagger\end{array}$ & $\begin{array}{c}\text { Dose } \\
(\mathrm{g} / \mathrm{L})^{\ddagger}\end{array}$ & $\begin{array}{c}\text { Length of } \\
\text { fermentat } \\
\text { ion (days) }\end{array}$ & $\begin{array}{c}\text { Win } \\
\text { lees } \\
(\%)\end{array}$ & $\begin{array}{c}\text { Wine } \\
\text { turbidit } \\
(\mathrm{NTU}) \S\end{array}$ & $\begin{array}{c}\text { Filter } \\
\text { type }\end{array}$ & $\begin{array}{c}\text { Filterability } \\
\text { index }\left(\mathrm{FI}_{\mathrm{T}}\right)^{\pi}\end{array}$ \\
\hline Wine 1 & & & & &
\end{tabular}

$\begin{array}{lllllllc}\text { Control } & \text { None } & 0.0 & 6.0 & \text { ND } & \text { ND } & \text { PF }^{\mathrm{c}} & 1 \pm 0 \\ k \mathrm{~N}-\mathrm{J} & \text { Juice } & 1.2 & 7.0 & \mathrm{ND} & \mathrm{ND} & \mathrm{PF} & 7 \pm 4 \\ k \mathrm{~N}-\mathrm{F} & \text { Ferment } & 1.2 & 8.0 & \mathrm{ND} & \mathrm{ND} & \mathrm{PF} & 16 \pm 13 \\ k \mathrm{~N}-\mathrm{W} & \text { Wine } & 1.4 & \mathrm{ND} & \mathrm{ND} & \mathrm{ND} & \mathrm{PF} & 1 \pm 0 \\ k i-\mathrm{J} & \text { Juice } & 1.2 & 7.3 & \mathrm{ND} & \mathrm{ND} & \mathrm{PF} & 3 \pm 1 \\ k i-\mathrm{F} & \text { Ferment } & 1.2 & 8.0 & \mathrm{ND} & \mathrm{ND} & \mathrm{PF} & 10 \pm 13 \\ k i-\mathrm{W} & \text { Wine } & 1.0 & \mathrm{ND} & \mathrm{ND} & \mathrm{ND} & \mathrm{PF} & 1 \pm 0 \\ \text { Bentonite } & \text { Wine } & 1.5 & 6.0 & \mathrm{ND} & \mathrm{ND} & \mathrm{PF} & 1 \pm 0\end{array}$

Wine 2

$\begin{array}{llcccccc}\text { Control-p } & \text { None } & 0.0 & 10.0 & 8.3 \mathrm{a} & 12.9 \mathrm{~b} & \mathrm{CF}^{\mathrm{d}} & 1 \pm 0 \\ k \mathrm{~N}-\mathrm{Jp} & \text { Juice } & 1.0 & 10.6 & \mathrm{ND} & \mathrm{ND} & \mathrm{CF} & 1 \pm 0 \\ k \mathrm{~N}-\mathrm{Fp} & \text { Ferment } & 1.0 & 11.6 & 5.5 \mathrm{~b} & 4.3 \mathrm{~d} & \mathrm{CF} & 1 \pm 0 \\ k \mathrm{~N}-\mathrm{Wp} & \text { Wine } & 1.4 & \mathrm{ND} & 7.0 \mathrm{a} & 11.9 \mathrm{~b} & \mathrm{CF} & 1 \pm 0 \\ & & & & \mathrm{~b} & & & \\ k i-\mathrm{Jp} & \text { Juice } & 1.0 & 10.0 & \mathrm{ND} & \mathrm{ND} & \mathrm{CF} & 1 \pm 0 \\ k i-\mathrm{Fp} & \text { Ferment } & 1.0 & 11.0 & 7.1 \mathrm{a} & 5.6 \mathrm{~cd} & \mathrm{CF} & 1 \pm 0 \\ & & & & \mathrm{~b} & & & \\ k i-\mathrm{Wp} & \text { Wine } & 1.4 & \mathrm{ND} & 10.0 & 21.2 \mathrm{a} & \mathrm{CF} & 1 \pm 0 \\ & & & & \mathrm{ab} & & & \\ k \mathrm{~K}-\mathrm{Jp} & \text { Juice } & 1.2 & 11.3 & \mathrm{ND} & \mathrm{ND} & \mathrm{CF} & 1 \pm 0 \\ k \mathrm{~K}-\mathrm{Fp} & \text { Ferment } & 1.2 & 11.3 & 8.2 \mathrm{a} & 4.0 \mathrm{~d} & \mathrm{CF} & 1 \pm 0 \\ & & & & \mathrm{~b} & & & \end{array}$




$\begin{array}{lccccccc}k \mathrm{~K}-\mathrm{Wp} & \text { Wine } & 1.4 & \mathrm{ND} & 8.8 \mathrm{a} & 9.9 \mathrm{bc} & \mathrm{CF} & 1 \pm 0 \\ & & & \mathrm{~b} & & & \\ \text { Bentonite-p } & \text { Wine } & 1.5 & 10.0 & 11.2 & 2.0 \mathrm{~d} & \mathrm{CF} & 1 \pm 0 \\ & & & & \mathrm{a} & & & \end{array}$

Values with different lowercase letters in the same column are statistically different. †Juice additions were made prior to cold-settling, ferment additions were made after a decrease of $2-3^{\circ} \mathrm{Be}$ and wine additions were made immediately after fermentation at the same time as $\mathrm{SO}_{2}$ addition. Juice for Wine 2 was treated with pectinase $(0.5 \mathrm{~g} / \mathrm{L})$ prior to fermentation. ${ }^{\ddagger}$ Dose rates were determined using a heat test. ${ }^{\S}$ Measure of wine clarity post-racking of fining agent and gross lees prior to filtration. "Wines with a filterability index $(\mathrm{FI})_{\mathrm{T}}>2.0$ have potential filterability issues. CF, crossflow filtration; F, fermentation; $l$, iota-carrageenan; $\mathrm{j}$, juice; $\kappa$-, kappa-carrageenan; $\kappa \mathrm{K}$, potassium-rich $\kappa ; \kappa \mathrm{N}$, sodium-rich $\kappa$; ND, not determined; p, pectinase treated; $\mathrm{PF}$, pad filtration; $\mathrm{W}$, wine. 
Table 5. Impact of carrageenan addition during large scale winemaking trials on protein concentration and heat stability post-bottling.

\begin{tabular}{|c|c|c|c|c|c|}
\hline Sample & $\begin{array}{c}\text { Protein } \\
\text { (mg/L) }\end{array}$ & $\begin{array}{c}\text { Heat stability } \\
\text { post-bottling } \\
(\Delta \mathrm{NTU})^{\dagger}\end{array}$ & Rating & $\begin{array}{c}\text { Heat } \\
\text { stability } 13 \\
\text { months } \\
(\Delta \text { NTU })^{\dagger}\end{array}$ & $\begin{array}{c}\text { Heat } \\
\text { stability } 25 \\
\text { months } \\
(\Delta \text { NTU })^{\dagger}\end{array}$ \\
\hline \multicolumn{6}{|l|}{ Wine 1} \\
\hline Control & $37.5 \mathrm{a}$ & $37.8 \pm 3.6$ & Fail & $37.0 \pm 7.7$ & $48.0 \pm 8.2$ \\
\hline$k \mathrm{~N}-\mathrm{J}$ & $2.7 \mathrm{~b}$ & $0.7 \pm 1.0$ & Pass & $0.8 \pm 0.4$ & $0.8 \pm 0.2$ \\
\hline$k \mathrm{~N}-\mathrm{F}$ & $2.5 \mathrm{~b}$ & $0.1 \pm 0.0$ & Pass & $0.3 \pm 0.1$ & $0.1 \pm 0.1$ \\
\hline$k N-\mathrm{W}$ & $3.9 \mathrm{~b}$ & $0.0 \pm 0.0$ & Pass & $0.1 \pm 0.1$ & $0.2 \pm 0.1$ \\
\hline$k i-J$ & $2.9 \mathrm{~b}$ & $0.9 \pm 0.7$ & Pass & $0.5 \pm 0.1$ & $0.8 \pm 0.7$ \\
\hline$k i-F$ & $2.5 \mathrm{~b}$ & $0.0 \pm 0.0$ & Pass & $0.1 \pm 0.1$ & $0.1 \pm 0.1$ \\
\hline$k i-\mathrm{W}$ & $3.5 \mathrm{~b}$ & $0.1 \pm 0.1$ & Pass & $0.2 \pm 0.2$ & $0.6 \pm 0.2$ \\
\hline Bentonite & $2.5 \mathrm{~b}$ & $0.0 \pm 0.0$ & Pass & $0.1 \pm 0.0$ & $0.6 \pm 0.5$ \\
\hline
\end{tabular}

Wine 2

$\begin{array}{lcclcl}\text { Control-p } & 24.3 \mathrm{a} & 78.0 \pm 2.9 & \text { Fail } & 89.9 \pm 5.2 & \text { ND } \\ k \mathrm{~N}-\mathrm{Jp} & 6.9 \mathrm{~b} & 1.8 \pm 1.7 & \text { Fail } & 3.9 \pm 3.3 & \text { ND } \\ k \mathrm{~N}-\mathrm{Fp} & 2.1 \mathrm{~cd} & 0.3 \pm 0.2 & \text { Pass } & 0.2 \pm 0.1 & \text { ND } \\ k \mathrm{~N}-\mathrm{Wp} & 1.7 \mathrm{~d} & 0.7 \pm 0.1 & \text { Pass } & 1.7 \pm 1.9 & \text { ND } \\ k i-J p & 4.5 \mathrm{bcd} & 1.3 \pm 1.2 & \text { Fail } & 3.0 \pm 2.1 & \text { ND } \\ k i-\mathrm{Fp} & 1.9 \mathrm{~cd} & 0.3 \pm 0.1 & \text { Pass } & 0.4 \pm 0.1 & \text { ND } \\ k i-W p & 2.0 \mathrm{~cd} & 1.2 \pm 0.5 & \text { Pass } & 0.5 \pm 0.2 & \text { ND } \\ k \mathrm{~K}-\mathrm{Jp} & 5.7 \mathrm{bc} & 2.0 \pm 1.2 & \text { Fail } & 4.8 \pm 2.3 & \text { ND } \\ k \mathrm{~K}-\mathrm{Fp} & 1.8 \mathrm{~cd} & 0.3 \pm 0.1 & \text { Pass } & 0.4 \pm 0.2 & \text { ND } \\ k K-W p & 2.1 \mathrm{~cd} & 0.9 \pm 0.4 & \text { Pass } & 0.7 \pm 0.5 & \text { ND } \\ \text { Bentonite-p } & 0.9 \mathrm{~d} & 0.0 \pm 0.0 & \text { Pass } & 0.1 \pm 0.0 & \text { ND }\end{array}$

Results are expressed as an average of each treatment replicate \pm one SD. For protein concentration, means with a different letter are significantly different $(P \leq 0.05) .{ }^{\dagger}$ Heat stability measured as the difference in NTU of a wine sample before heating $\left(80^{\circ} \mathrm{C}, 2 \mathrm{~h}\right)$ and after subsequent cooling $\left(20^{\circ} \mathrm{C}, 3 \mathrm{~h}\right)$. F, fermentation ; $\imath$, iota-carrageenan; $\kappa$-, kappacarrageenan; $\kappa \mathrm{K}$, potassium-rich $\kappa ; \kappa \mathrm{N}$, sodium-rich $\kappa$; J, juice ; ND, not determined for these samples; $\mathrm{p}$, pectinase ; $\mathrm{W}$, wine. 
Table 6. Composition of Sauvignon Blanc wines.

\begin{tabular}{|c|c|c|}
\hline & Wine 1 & Wine 2 \\
\hline Alcohol (\%) & $13.0 \pm 0.1$ & $13.4 \pm 0.1$ \\
\hline TA $(g / L)$ & $6.9 \pm 0.1$ & $6.4 \pm 0.1$ \\
\hline Residual sugar (g/L) & $0.4 \pm 0.1$ & $1.5 \pm 0.0$ \\
\hline $\mathrm{pH}$ & $3.3 \pm 0.0$ & $3.1 \pm 0.0$ \\
\hline Free $\mathrm{SO}_{2}(\mathrm{mg} / \mathrm{L})$ & $34.7 \pm 12.0$ & $39.2 \pm 2.0$ \\
\hline Total $\mathrm{SO}_{2}(\mathrm{mg} / \mathrm{L})$ & $120.4 \pm 16.4$ & $116.3 \pm 1.3$ \\
\hline Copper (mg/L) & $0.21 \pm 0.03$ & $0.02 \pm 0.01$ \\
\hline Iron (mg/L) & $1.92 \pm 0.10$ & $0.17 \pm 0.06^{\dagger}$ \\
\hline Manganese (mg/L) & $0.54 \pm 0.07$ & $1.28 \pm 0.07$ \\
\hline Zinc (mg/L) & $0.83 \pm 0.05$ & $1.44 \pm 0.04$ \\
\hline Magnesium (mg/L) & $77.9 \pm 6.9$ & ND \\
\hline \multicolumn{3}{|c|}{$\begin{array}{l}\text { Results are shown as the mean of all treatments (untreated } \\
\text { Control wines, bentonite-treated wines, and wines after } \\
\text { carrageenan addition to juice, fermentation or wine) } \pm \text { one } \\
\text { SD, except where indicated. }{ }^{\dagger} \text { Iron concentration for } \\
\text { bentonite-treated wine was } 0.86 \mathrm{mg} / \mathrm{L} \text { and was excluded } \\
\text { from the averaged value. ND, not determined for these } \\
\text { samples. }\end{array}$} \\
\hline
\end{tabular}


igure 2 Percent of protein removed by carrageenan treatment pre-bottling (blue) and post-bottling (red) when added at different stages of winemaking compared to the untreated control wines. a) Wine 1 b) Wine 2

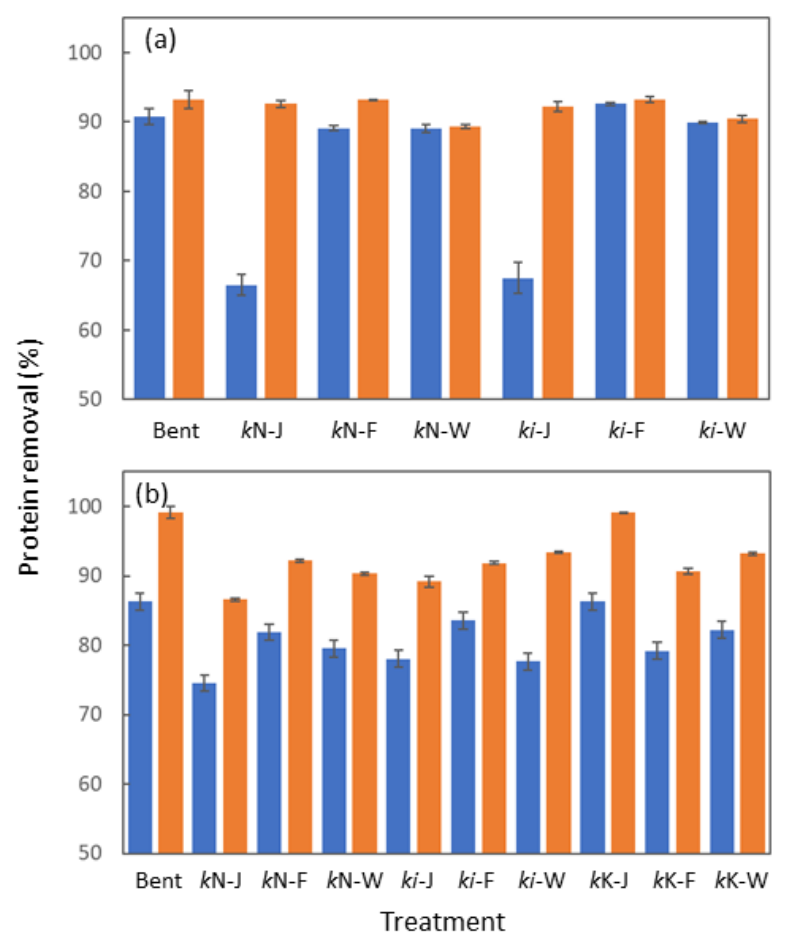

AJGW_12411_Stockdale Figure 2 18-115 R4.tif

This article is protected by copyright. All rights reserved. 


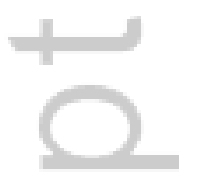

(3.

Figure 3 . Concentrations of metal

addition of heat-stabilising agents

including control (blue), bentonite

(Bent) (orange), kappa-carrageenan with sodium ions ( $\mathrm{kN}$ ) (grey), kappa-

iota carrageenan blend (ki) (yellow) and kappa-carrageenan with potassium ions (kK) (green). a) sodium, b) potassium, c) calcium concentrations. Results are shown as the average of different treatment times \pm one standard deviation.
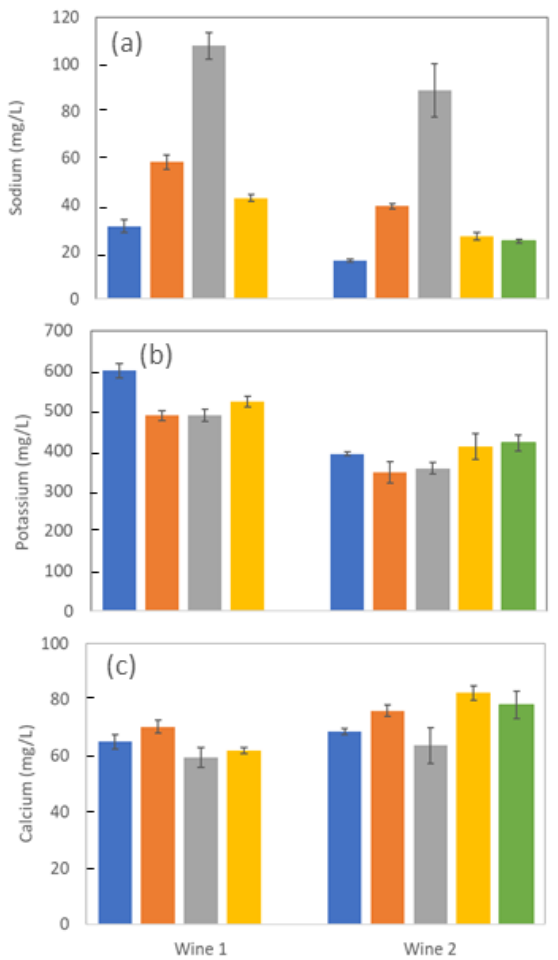

AJGW_12411_Stockdale Figure 3 18-115 R3.tif

This article is protected by copyright. All rights reserved. 
Figure 4. Sensory analysis for Wine 1 presented as a) Spider plot and b) Scores and loadings bi-plot for PCA of sensory attributes that varied significantly with carrageenan type or addition time for heat-stabilised wines, bentonite-treated wines and untreated control wines. Carrageenan types and addition times include kappa-iota (kiK) juice addition (green), kiK ferment addition (light blue), kiK wine addition (dark blue), kappa $(\mathrm{kN})$ juice addition (grey), $\mathrm{kN}$ ferment addition (orange), $\mathrm{kN}$ wine addition (yellow), bentonite control wine (medium blue), untreated control wine (brown).

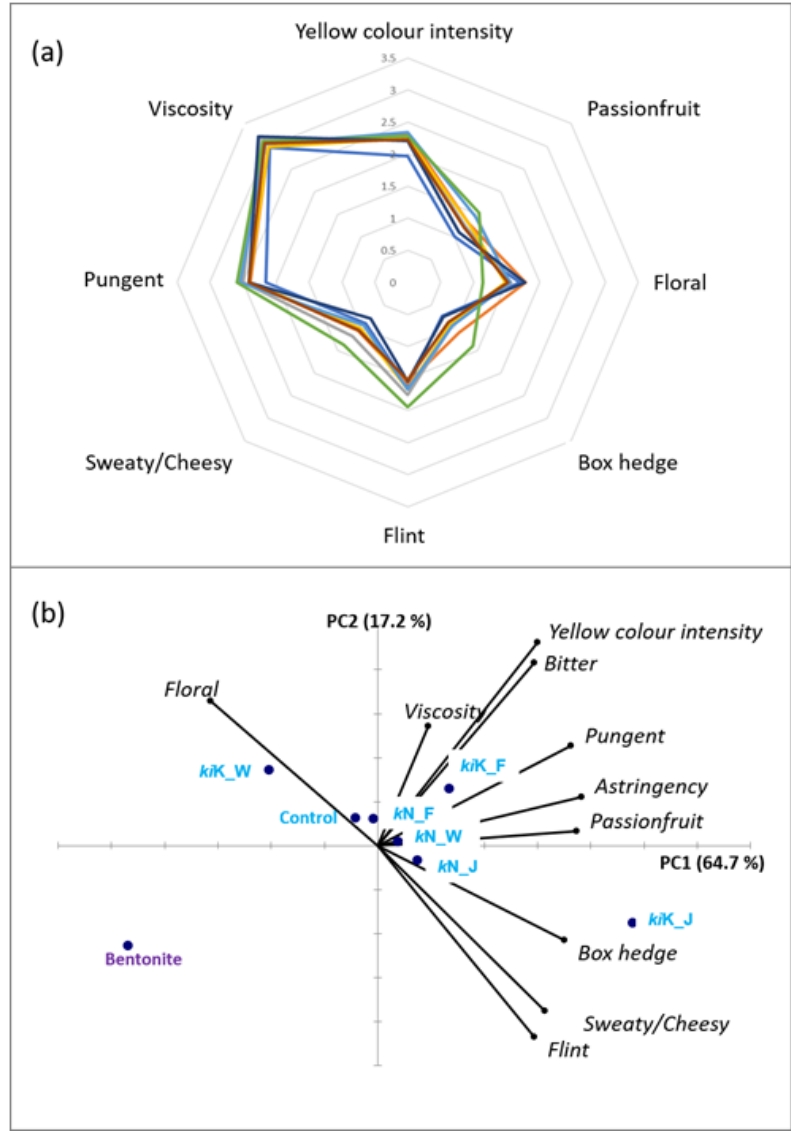

AJGW_12411_Stockdale Rev Figure 4 18-115 R4.tif 


\section{University Library}

\section{- M M N E R VA A gateway to Melbourne's research publications}

Minerva Access is the Institutional Repository of The University of Melbourne

Author/s:

Ratnayake, S;Stockdale, V;Grafton, S;Munro, P;Robinson, AL;Pearson, W;Mcrae, JM;Bacic, A

Title:

Carrageenans as heat stabilisers of white wine

Date:

2019-10-01

Citation:

Ratnayake, S., Stockdale, V., Grafton, S., Munro, P., Robinson, A. L., Pearson, W., Mcrae, J. M. \& Bacic, A. (2019). Carrageenans as heat stabilisers of white wine. AUSTRALIAN JOURNAL OF GRAPE AND WINE RESEARCH, 25 (4), pp.439-450. https://doi.org/10.1111/ ajgw.12411.

Persistent Link:

http://hdl.handle.net/11343/286415 